Espacio, Tiempo y Forma, Serie II, Historia Antigua, t. 23, 2010, págs. 411-448

\title{
Criadores hispanos de caballos de carreras en el Bajo Imperio en las cartas de Símaco
}

\author{
Hispanic horses-breeders for racehorses in Late Roman Empire \\ in the letters of Symmachus
}

José María BLÁZquez Martínez*

\begin{abstract}
RESUMEN
ABSTRACT

Se recogen todas las menciones de

This article presents all the mentions of hispanic horses in the ancient authors. Teh horsebreeders in Hispania. The marks of the Group of breeding mares. The names of the owners. The exportation of hispnic horses in the second Century. They have been high Speedy. Portraits of horses and car.drivers. The circus.

hispanos y de aurigas. Los circos.

PALABRAS CLAVE:

KEYWORDS:

Caballos hispanos. Criadores. Marcas. Nombres. Exportaciones. Retratos. Circos.

Hispanic Horses. Breeders. Marks. Names. Exportation. Portraits. Circus

Hispania, en el Bajo Imperio ${ }^{1}$ tenía fama por criar caballos de carreras, que exportaba a Roma y a otras provincias del Imperio.

* Real Academia de la Historia. Universidad Complutense de Madrid

1 BLÁZQUEZ, J.M., Economía de la Hispania Romana, Bilbao 1978, pp. 485-618; Id., Historia económica de la Hispania Romana, Madrid 1982, pp. 525-607; Id., Nuevos Estudios sobre la Romanización, Madrid 1989, pp.451-525, 573-641; Id., Aportaciones al Estudio de la España Romana en el Bajo Imperio, Madrid 1990; Id., Urbanismo y Sociedad en Hispania, Madrid 1991, pp. 401-432; Id., España Romana, Madrid 1996, pp. 365-466; Id., El Mediteráneo y España en la Antigüedad, Madrid 2003, pp. 765796; Id., El Mediterráneo. Historia. Arqueología. Religión. Arte, Madrid 2006, pp. 283-313; Id., Arte y religión en el Mediterráneo Antiguo, Madrid 2008, pp. 423-424; SAYAS, J.J., Historia Antigua de España. II. De la Antigüedad Tardía al ocaso visigodo, Madrid, 2001; GARCÍA MORENO, L., El Bajo Imperio, Madrid 1999.
\end{abstract}


Flavio Vegetio Renato (383-450), que fue comes $^{2}$, en su Digesta artis mulomedicinae (I.56.37) escribe que el paso portante que él llama tolutim ambulare de los caballos partos, es parecido al de los asturcones, célebres caballos hispanos muy renombrados en época imperial, mencionados por vez primera en el compendio de retórica publicado a petición de C. Herennio, atribuido a Cicerón y fechado entre los años 86 y 82 a.C., que lleva por título De ratione dicendi ad Herennium (IV.62); por P. Virgilio Varrón, en época de Augusto, en su Eneida (X.180; Georg. III.266.272-278), como caballo muy hermoso; por T. Petronio Arbiter, en tiempos de Nerón (Sat. 86.4); por Plinio el Viejo, en tiempos de la Dinastía Flavia, en su Historia Natural (IV.166; VIII.86.4.166; XVI.93), que afirma: «Es verdad que en Lusitania, en los alrededores del oppidum de Olisipo y del Tajo, las yeguas vueltas hacia el viento favonio respiran sus fecundantes auras, preñándose de este modo, pero su vida no pasa de tres los años. En la misma Hispania hay un pueblo gallego y astur, en los que se crían los caballos llamados tieldones y asturcones, cuando son de talla menor; no tienen un paso como el corriente, sino que su paso es suave y procede del movimiento simultáneo de las dos patas de un mismo lado. Por ello se ha educado a los caballos a marchar en ambladura». Plinio (XVI.93) repite la misma noticia de las yeguas lusitanas ${ }^{3}$. Los caballos astures los menciona Silio Itálico (25-101) en su epopeya Punica (XVI.348), que celebra a un caballo de carreras asturiano llamado Panchates, pequeño, poco vistoso, con marcas blancas en la frente y en los corbejones; muy blando de boca y muy rápido. El poeta satírico Marcial, a finales del s. I, en su Epigrama (XVI.199), describe al asturcón ${ }^{4}$ : este caballo pequeño, astur, que galopa rápidamente al son del compás,

Se han utilizado las ediciones de las cartas de Símaco: VALDÉS, J.A., Símaco. Cartas. Libros I-V, Madrid 2000; Id., Símaco. Cartas. Libros VI-X, Madrid 2003; CALLU, J.R., Symmaque. Lettres. Tome II (Livres III-V), París 1982.

Agradezco la ayuda prestada al prof. D. Luis Ruiz de la UCM y a la Srta. L.F. Humanes.

2 JONES, A.H.M., MARTINDALE, J.R., MORRIS, J., The Prosopography of the Later Roman Empire, I. A.D., 260-395, Cambridge 1971, p. 763.

3 CANTO, A.M., "Un "mito" homérico en Iberia: Zephirus y las yeguas de Olimpo. Nuevos textos y ensayos de explicación desde la Genómica», Lusitania Romana. Entre mito y realidad. Actas de la VI Mesa Redonda Internacional sobre Lusitania Romana, Cascaris 2009, pp. 165-218; BLÁZQUEZ, J.M., Diccionario de las Religiones Prerromanas de Hispania, Madrid 1975, p. 55; Id., Religiones primitivas de Hispania. I. Fuentes literarias y epigráficas, Madrid 1962, pp. 24-25; Id., «La religión de los pueblos de la Península Ibérica. Salamanca. Cáceres», Zephyrus 43, 1990, pp. 223-333; BLAZZUEZ, J.M., GARCÍAGELABERT, M.P., «Mitos hispánicos», MARTíNEZ-PINNA, J. (ed.), Mitología y ritual en el Antiguo Occidente Mediterráneo, Málaga 2003, pp. 197-220.

Sobre Lusitania: GORGES, J-G., NOGALES, T. (eds.), Naissance de la Lusitanie Romaine (1 ${ }^{\text {er }}$ av.$1^{\text {er }}$ ap. J.C.). Origen de la Lusitania Romana (siglos 1 a.C.-1 d.C.). VII Table Ronde Internationale sur la Lusitanie Romaine, Toulouse-Mérida 2010; MARTíN BRAVO, A.M., Los orígenes de Lusitania. El I miIenio a.C. en la Alta Extremadura, Madrid 1999.

${ }^{4}$ BLÁZQUEZ, J.M., Imagen y mito. Estudios sobre las religiones mediterráneas e ibéricas, Madrid, 1997, pp. 266-277; RABANAL, M.A., GARCÍA MARTÍNEZ, Epigrafía romana de la provincia de León: Revisión y actuaización, León, 2001, pp. 386-387; lám. LXXXVI.2; 390-391, lám. LXXXVII.2; 392-393, lám. LXXXVII.4; 394-395, lám. LXXXVIII.2; 396-397; 395-396, lám. LXXXVIII.3, lám. LXXXVIII.4; 399-400, lám.LXXXIX.1; 402, lám. LXXXIX.4; 404-405, lám. XC.3; 407.408, lám. XCI.1; 409-410, la m. XCI.3; 418419, lám. XCIII.4; 420-421, lám. XCIV.2; 421-422, lám. XCIV.3; 422-423, lám. XCV.1; 424-425, lám. XCV.2; 425-426, lám. XCVI.3.

Algunas lápidas hacen constar que son vadienses. Sobre éstos véase: SASTRE PRAT, Onomástica y relaciones políticas en la epigrafía del Conventus Asturum durante el Alto Imperio, Madrid 2002. 
viene de la gente rica en oro. Granio Liciniano, en el s. III, recoge la mención más antigua del caballo asturcón, que montó Antioco IV Epifanes en la fiesta que celebró en 167 a.C. en Antioquía. El lexígrafo titulado Corpus glosariorum latinorum, datado a finales de la Antigüedad (V.169.22), menciona al caballo asturcón, al que califica de andador. Junto a los asturcones, el poeta Grattio (V.513), a comienzos del Imperio, cita a los caballos de Gallaecia, de los que afirma que no son aptos para la guerra por no admitir el bocado.

Las razas hispanas famosas de caballos eran, pues, la galaica, la astur y la lusitana. Los caballos astures están representados en las estelas vadinienses.

Flavio Vegecio Renato, más adelante de su Digesta artis mulomedicinae (III.6.4), recoge dos noticias importantes, cuales son que los caballos capadocios eran preferidos a los hispanos, y que en África ${ }^{5}$ se criaban caballos idénticos a los hispanos. Una tercera noticia recogida (III.7.1) era que los caballos hispanos y númidas eran de vida más corta que los persas, huniscos, epirotas y sicilianos.

Trogo Pompeyo, historiador oriundo de la Narbonense, contemporáneo de Augusto, en su Laus Hispaniae, recogida por Justino en su Epitoma historiarum Philippicarum Pompei Trogi (XLIV.31 y 36), escribe: «Muchos autores han contado que entre los lusitanos que habitan junto al río Tajo, las yeguas conciben sus crías del viento, fábula que tiene su origen en la fecundidad de las yeguas y en la multitud de sus rebaños, los cuales pueden verse, tanto en Gallaecia como en Lusitania, en tan alto número y tan veloces, que no sin razón parecen como concebidos por el mismo viento". El párrafo afirma la velocidad de los caballos hispanos y la gran abundancia de ellos, dato éste último confirmado por Estrabón (III.4.15) en su Geografía.

El geógrafo de Amaseia indica que los caballos están acostumbrados a escalar montañas y a flexionar rápidamente las manos a una orden dada en momento oportuno, y que lberia producía un gran número de rebecos y de caballos salvajes.

La leyenda de las yeguas lusitanas está recogida por muchos autores de la Antigüedad: por M. Terencio Varrón (118-30 a.C.) (De re rust. II-I.19), cuyo testimonio es e mucho valor por haber permanecido en Hispania mucho tiempo durante la guerra sertoriana a las órdenes de Pompeyo (Sall. Hist. II.29) y durante la guerra civil entre César y Pompeyo (BC. I.38.25; II.17.1), que tenía la Bética con dos legiones; por L. Junio Moderato Columela, natural de Cádiz (De re rust. VI-XXVII.47); por Silio Itálico (III.378-383; XVI.363-365; 426-433); por Claudio Aeliano (175235) (De nat. anim. IV.6); por Lactancio (264-340) (Inst. diu. IV.12); Cayo Julio Solino (290-350) (Collectanea rerum memoriabilium sive De mirabilis mundi 27.7); por Quinto de Esmirna (segunda mitad del s. IV) (Posth. III. 746-751); por Marciano Capela (después del 410) (De muptiis Philologiae et Mercurii liber VI: De Geo-

5 LÓPEZ MONTEAGUDO, G., «Inscripciones sobre caballos en mosaicos de Hispania y del Norte de África», L'Africa Romana IX, 1991, pp.967-1010; SALOMONSO, J.W., La mosaïque du chevaux de l'Antiquarium de Carthago, Le Haye 1965. 
metria, 629); por Agustín (413-426) (De civ. Dei XXI.5); por Isidoro de Sevilla (560-636) (Ethym. XX.IX.5.28; XII.I.44).

La tesis de M. Canto es que esta leyenda es el más antiguo mito de lberia y de Occidente, en la llíada de Homero. Homero (II. XVI.149-152) celebra:

Luego, Patroclo mandó a Automedonte —el amigo a quien más honraba después de Aquiles, el destructor de hombres, y el más fiel en resistir a su lado la acometida del enemigo en las batallas- que enganchara los caballos. Automedonte unció bajo el yugo a Xanto y Balio, corceles ligeros que volaban como el viento y tenían por madre a la harpía Podarga, la cual los concibió del viento Céfiro mientras se hallaba pastando en una pradera a las orillas del Océano. $Y$ con ellos puso al excelente Pédaso, que Aquiles se llevara de la ciudad de Eetión cuando la tomó, corcel que, no obstante su condición de mortal, seguía a los caballos inmortales.

Los textos referentes a los caballos hispanos y a sus cualidades son numerosos.

Plinio (XXXVII.203) en su Historia Natural hace una laus Hispaniae y afirma que abunda en caballos. El autor de la Expositio totius mundi et gentium, un oriental que escribe su obra a mediados del s. IV, escribe que los mejores caballos podían obtenerse en Capadocia, Hispania, Numidia, África, Pentapolitania, Sicilia y Cerdeña. El Corpus Hippiaticorum Graecorum (2.123.15; 24.4), que recoge la opinión de veterinarios antiguos, principalmente del s. IV, compara a los caballos hispanos con los de Marruecos y Libia, que eran, junto a los de Arcadia, Capadocia y Tesalia, regiones productoras de caballos de raza en la Tarda Antigüedad. Oppiano (Cyneg. I.282-290), en torno al 177, compara, igualmente, los caballos hispanos con los africanos, afirmando que los primeros son más veloces que los últimos. Este autor afirma también que los mejores caballos eran los de Capadocia, de Hispania y de Grecia, y que los caballos hispanos eran más rápidos que los partos (Cyneg. 1.278.279). El último gran historiador de la Antigüedad, Ammiano Marcelino (20.8.13), amigo del emperador Juliano, menciona los caballos hispanos de carreras como animales importantes para correr en el hipódromo. El poeta Claudio Claudiano, de finales de la Antigüedad, natural de Alejandría, que vivió en Roma, menciona varias veces los caballos hispanos como famosos para correr en el circo (Paneg. 285.87; Carm. min. 47.36). El poema que lleva por título Laus Serenae (Carm. min. 30.54) califica a Hispania rica en caballos. Duda (Carm. min. 47.36) de la procedencia del caballo del emperador Honorio, entre Hispania, Capadocia y Tesalia.

Las frecuentes menciones de los caballos hispanos en autores que vivieron en el Bajo Imperio, demuestra que eran famosísimos, y la existencia de muchas yeguadas en Hispania. La fama de los caballos hispanos remonta a finales de la República Romana, pero se mantuvo a los largo del Imperio. 
En Lusitania nació el as del circo romano, el hispano Diocles, del bando rojo, que obtuvo más victorias y ganó más dinero ${ }^{6}$. Se conocen bien todos sus éxitos y ganancias gracias a la detallada descripción de ellos en el CIL VI.10.048, que dice:

C. Apuleius Diocles, agitator del bando rojo, de nación española, de la Lusitania, con cuarenta y dos años, siete meses y veintitrés días. Comenzó corriendo en la facción alba siendo cónsules Acilius Aviola y Cornelius Pansa. Su primera victoria la tuvo corriendo por el bando blanco, siendo cónsules M. Acilius Glabrio y C. Bellicus Torquatus. Comenzó a correr en la facción verde, siendo cónsules por segunda vez Torquatus Asprenas y Anniud Libo. Venció por vez primera, corriendo por el bando rojo, en el consulado de Laenas Pontianus y Antonius Rufinus. Resumiendo: Condujo cuadrigas durante veinticuatro años, corriendo 4.257 veces, venciendo 1.462 y de ellas 110 en carreras de honor celebradas a comienzo de la fiesta. En carreras de un solo carro por cada uno de los cuatro bandos, venció 1.064 veces, de ellas 92 veces en certámenes en los que se disputaban premios en dinero: estas últimas se distribuyen así: 32 victorias en las que el premio era de 30.000 sestercios, de ellas, tres con carros tirados por seis caballos; 29 victorias en las que el premio consistió en 50.000 sestercios; de ellas, una con carros tirados por siete caballos; tres victorias con premio de 60.000 sestercios. En carreras en las que por cada facción corrían dos carros, venció 387 veces; cuatro de ellas ganando un premio de 15.000 sestercios y corriendo con carros de tres caballos. En carreras en las que cada bando corría con tres carros, triunfó 51 veces. Obtuvo premios de varias clases en 1.462 carreras; segundos premios, 861 veces; terceros, 576 veces; cuarto, una sola vez, y con premio de 1.000 sestercios, y no se clasificó 1.351 veces. Con el bando azul venció 10 veces; con el blanco, 91, de ellas dos con sendos premios de 30.000 sestercios. Ganó en total 35.863 .120 sestercios, venciendo con carros de dos caballos que ya habían triunfado en mil o más carreras, tres veces, de ellas corriendo una en la facción de los blancos y dos en la de los verdes. Se mantuvo a la cabeza desde el comienzo hasta el fin de la carrera, venciendo al final 815 veces; pasó del segundo lugar al primero ganando la carrera 67 veces; fue dejado atrás, recuperando luego el primer puesto y ganando al final de la carrera, 36 veces. En otros géneros de certámenes triunfó 42 veces. En carrera difícil ganó al final, con un último esfuerzo, 502 veces; de ellas, 216 corriendo para los verdes, 205 para los azules y 81 para los blancos. Hizo que nueve caballos llegasen a alcanzar cada uno más de cien triunfos, y que dos caballos alcanzasen cada uno 200 victorias. Según consta en las actas de su facción, Avilius Teres fue el primero que consiguió llegar a las 1.011 victorias, de las que [...] fueron ganadas en un solo año. Pues bien, Diocles fue el primero que en un solo año llegó a alcanzar 1.000 victorias, venciendo 103 veces; de ellas, 83 en carreras de un solo carro, por color, a más de ello, acreciendo la gloria de sus méritos, superó a Thallus, de su misma facción, primero que en el bando rojo [...]. Pues bien, Diocles, el más destacado de todos los agitatores, en un año venció 134 veces llevando en el

${ }^{6}$ GARCÍA y BELLIDO, A., Veinticinco estampas de la España Antigua, Madrid 1967, pp. 140-147. Diocles fue en el circo de Roma lo mismo que Porphirius en Bizancio (CAMERON, A., Porphirius The Charioteer, Oxford 1973). 
lado izquierdo un caballo ajeno; de ellas, 118 fueron certámenes en los que corría un carro por cada color. Con ello Diocles superó a todos los agitatores de todos los colores que hayan tomado parte nunca en juegos circenses. De todos fue percibido y admirad el hacho de que en un solo año, corriendo con un caballo ajeno en el lado izquierdo y dos en el centro, donde iban los caballos Cotynus y Pompeianus, venciese 99 veces, una de ellas jugándose un premio de 60.000 sestercios, cuatro de 50.000 , uno de 40.000 y dos de 30.000 sestercios [...] de la facción verde, venció 1.025 veces, siendo el primero desde los más remotos tiempos de Roma que venció en siete carreras con premios de 50.000 sestercios. Pero Diocles superándolo y llevando en su cuadriga a tres caballos ajenos, Abigeius, Lucidus, y Paratus, venció ocho veces en carreras en las que el premio era de 50.000 sestercios. Asímismo, superando a Communis Venustus y Epaphroditus, tres agitatores miliarios de la facción azul, que lograron vencer 11 veces en carreteras de 50.000 sestercios de premio. Diocles, llevando en el centro de la cuadriga a los caballos Pompeianus y Lucidus, logró vencer en carreras cuyos premios eran de 50.000 sestercios más de 12 veces [...] de las facción verde, vencedor 1.025 veces, y Flavius Scorpus, vencedor en 2.048 carreras, y Pompeius Musciosus, vencedor en 3.559 certámenes, tres agitatores que en junto vencieron en 6.632 carreras, llevándose de ellas 28 premios de 50.000 sestercios, a todos aventajó Diocles, el más sobresaliente de todos los agitatores, ya que logró triunfar en 1.462 carreras, de ellas 29 premiadas con 50.000 sestercios. Con nobilísimo esplendor brilla el nombre de Diocles al ver que si Fortunatus, de la facción de los verdes, corriendo con el caballo vencedor de nombre Tuscus, logró 386 victorias y de ellas nueve de 50.000 sestercios de premio. Diocles, corriendo con el caballo vencedor Pompeianus, en sólo 152 victorias obtuvo 10 premios de 50.000 sestercios y uno de 60.000 . Diocles descolló alcanzando nuevas marcas registradas antes de él, ganando en un solo día dos carreras de 40.000 sestercios de premio con carros tirados por seis caballos y aún más [...] con un tiro de siete caballos uncidos entre sí, espectáculo nunca visto hasta entonces con tal número de caballos, ganó un certamen de 50.000 sestercios y descolló victorioso con Abigeius y sin látigo; salió victorioso de otros concursos con premios de 30.000 sestercios. Y como estas novedades se vieron entonces por vez primera, Diocles se adornó de doble gloria. Según se dice, el que va a la cabeza de todos los agitatores miliarios es Epaphroditus, agitator de la facción azul, el cual, en tiempo de nuestro emperador Antoninus Pius Augustus, venció 1.467 veces, de ellas 940 en carreras de un solo carro por facción. Pues bien, Diocles, sobrepasándole, resultó vencedor en 1.962 carreras, de ellas 1.064 de un solo carro por color. En estos mismos tiempos Pontius Epaphroditus venció 467 veces en carreras malas, ganadas en un arranque final. Pues bien, Diocles, con este mismo modo de victoria, obtuvo el triunfo 502 veces. El agitator Diocles en este año venció 127 veces, de ellas 103 con los caballos Abigeius, Lucidus y Pompeianus, uncidos en el centro de ellas [...] entre destacados agitatores vencieron muchas veces llevando de introyugos a Afer, Pontius Epaphroditus, de la facción azul, venció con Bubalus 134 veces; Pomepius Musclosus, del color verde, con el caballo [...] salió victorioso en 115 carreras. Diocles, empero, sobrepasó a todos, resultando vencedor con Pompeianus 152 veces, de las que 144 lo fueron en carreras de un solo carro por facción. Y, aumentando su gloria, obtuvo 445 victorias llevando como in- 
troiugi cinco caballos: Cotynus, Galata, Abigeius, Lucidus y Pompeianus, de las 397 ganadas en carreras de un solo carro por color.

(Traducción de A. García y Bellido)

Q. Aurelio Símaco7, uno de las grandes figuras paganas del Bajo Imperio, desempeñó las más altas magistraturas: fue cuestor antes del 365; prefecto de la ciudad de Roma, 365; Pontifex Maximus alrededor del 365; corrector Lucaniae et Brittiorum, 365; comes ordinis tertii; proconsul Africae; 373; lider de la aristocracia pagana de Roma y excelente orador. Era inmensamente rico, pues tenía fincas en África (Ep. VIII.20), en Sicilia (Ep. IX.52), en Apulia (Ep. VI.12), en Campania (Ep. I.1), y otras muchas ciudades de Italia.

Con motivo de celebrar la prefectura de su hijo en Roma y organizar carreras de carros en el circo, pidió a diferentes criadores de caballos de Hispania, repetidas veces, caballos para correr en el circo de Roma. Se conservan las cartas que dirigió a los hispanos, que son las siguientes.

La primera carta (Ep. IV.58.2) es del año 399, y va dirigida a Eufrasio ${ }^{8}$, magister officiorum. En ella le pide cuatro de sus caballos de carreras. Eufrasio se había olvidado de elegirlos. Puntualiza que son para los juegos pretorianos de su hijo. Solicita que sean de raza. Deja a su juicio el precio del coste de la cuadriga, que hay que pagar a los propietarios de caballos de raza. Afirma que es fácil la elección, pues Hispania es rica en caballos y hay un gran número de yeguadas donde elegir.

En carta datada un año antes, 398 (Ep. IV.59), anuncia lo mismo que repite un año después, que su hijo ha logrado la prefectura urbana de Roma, y que necesita una cuadriga. Le indica que le enviará el dinero el próximo verano.

La elección de los caballos debe efectuarse ya, pues en asuntos parecidos importa mucho ser diligente. Este párrafo prueba la alta estima qn que tenía a los caballos hispanos y la preocupación de que no fallara el envío, por eso acude con tiempo.

En carta (Ep. IV.LX) al mismo Eufrasio, insiste sobre lo ya indicado. Tiene que prevenir la presencia de caballos en la carrera, de pura sangre, pues no valía cualquiera, pagados por Símaco y elegidos por Eufrasio, que respondan a las esperanzas del pueblo romano. Sin tardanza debe calcular la cantidad de dinero a pagar, según su equidad. Los caballos serán, o de sus yeguadas, o seleccionados entre el ganado de otros criadores, lo que no plantea problemas al ser Hispania rica en caballos de carreras.

Símaco ya se había interesado años antes, 391, en obtener caballos de carreras de Eufrasio (Ep. IV.LXII). Le había escrito que el prestigio de sus caballos se había extendido lejos. Le comunica que cada magistrado, atraído por el prestigio

7 JONES, A.H.M., MARTINDALE, J.R., MORRIS, J., Op. cit., pp. 865-870.

8 JONES, A.H.M., MARTINDALE, J.R., MORRIS, J., Op. cit., p. 294. 
de sus caballos, le reclama que los ayude, recomendándolos. Así sucede que los notables de Antioquía, encargados de comprar cuadrigas de caballos, querían que los apoyara él con unas palabras de recomendación. Habían solicitado, después de un largo viaje, benevolencia equitativa en la elección y en la evaluación de los animales. Se vieron confirmadas sus esperanzas. Esta breve carta es significativa. Confirma las buenas relaciones de Símaco con Eufrasio; la importancia de éste como criador de caballos; la fama de los caballos hispanos, que llegó hasta Antioquía, donde eran muy cotizados, y las gestiones favorables de Símaco con Eufrasio.

La carta de Símaco IV.LXIII, fechada en el 400, dirigida al mismo Eufrasio, trata del mismo tema, que preocupaba mucho a Símaco, la obtención de caballos hispanos. La pretura le incita a desear un mayor número de caballos. Como es habitual, agradaba a Eufrasio ocuparse de los encargos de Símaco. Señala que la navegación se abre en primavera. Le encarga cuatro tiros de caballos que elija entre las yeguadas de las gentes de Laodicea que, según la interpretación de J.P. Callu, serían gentes de Laodicea llegados a Hispania, o de sirios instalados en Occidente. también puede tratarse de un apodo dado a los hispanos que traficaban con los habitantes de Laodicea. Símaco le escribe que completaría el precio señalado en la carta. Le comunica que los caballos de Eufrasio son los mejores de Hispania. Deja a su celo hacer la selección y obtener de otras yeguadas caballos de igual renombre que los de Eufrasio. Símaco tiene absoluta confianza en su amigo Eufrasio. Sus caballos son los mejores, pero si no dispone de un número suficiente de animales, puede elegir otros caballos de otras yeguadas que sean de la misma calidad. Siempre confirma Símaco el pago.

Símaco conocía otros dueños de yeguadas a los que solicita caballos en Hispania. A Flavio Julio Salustio, que fue el prefecto de la ciudad de Roma ${ }^{9}$, cónsul y vicario de las Hispanias, le envía una carta (V.56) en el año 401. Le había pedido que los comisionados fueran ayudados por él en la búsqueda de caballos de tiro. Había aumentado el número a cuatro cuadrigas. De ellas, once animales han sobrevivido y han llegado al destino gracias a los cuidados de los servidores. Poco después, unos cuantos murieron. El azar no ha disminuido los favores de su escrupuloso comportamiento. Símaco estaba agradecido, a pesar de la pérdida del ganado. Le comunica que, por intermediario de su agente, le ha enviado el díptico de la candidatura y dos libras de plata como recuerdo. Nada tiene de extraño que Salustio tuviera rebaño de caballos en Hispania, pues su padre, Flavio Salustio, que había desempeñado el consulado en 363, fue vicario de las Hispanias.

Otras cartas de Símaco se enviaron a otros criadores de caballos en Hispania. Así, la carta IV.7, dirigida a Estilicón ${ }^{10}$, uno de los hombres más poderosos del Imperio, se fecha en 399. Le pide que, según su gran corazón, ordene el envío en ruta inmediato de gentes de confianza que había enviado a Hispania a buscar caballos de carreras. Está presionado por la proximidad de la fecha de los juegos pró-

9 JONES, A.H.M., MARTINDALE, J.R., MORRIS, J., Op. cit., p. 795.

10 JONES, A.H.M., MARTINDALE, J.R., MORRIS, J., Op. cit., pp. 853-858. 
ximos. Solicita de él que envíe cartas a sus amigos para facilitar la realización de sus deseos. Símaco estaba agobiado por la obtención de caballos hispanos y acude a las personas más influyentes, para que le ayuden a obtener sus deseos. Puntualiza que ha enviado agentes de confianza a Hispania con el fin de obtener los caballos.

La carta V.82 es muy significativa. Está enviada a Helpidoro'11. Se fecha en 399. Menciona la obtención de caballos, que de todos los tiros que le ha escrito que están en venta, selecciones la flor de aquellos animales que valgan por su nacimiento. Está preocupado porque la fama de los próximos juegos esté a la altura de nuestros juegos anteriores. Le pide que no preste importancia al número, sino a la calidad de los animales. Afirma de paso lo que ya escribió en otras cartas, que Hispania es abundante en caballos. Puede elegir caballos de otras yeguadas vecinas. Las cartas tienen el mismo tema, pero prueban la gran preocupación de Símaco por obtener los caballos, seguramente por considerarlos los mejores que se pueden obtener en el mercado.

En la carta VII.48, dirigida a Hadriano, datada en 399, agradece a Hadriano ${ }^{12}$, que desempeñó las magistraturas de comes largitiorum, 395; magister officiorum, 397-399; praefectus praetorio Italiae et Africae, 401-405; praefectus praetorio Italiae et Africae, 413-414, que unos amigos enviados a Hispania para comprar caballos para los carros, puedan utilizar los servicios de la caballería del Estado, como otras veces (Ep. I.21 y IV.7). Solicita que los enviados hagan pronto la travesía, pues se necesita mucho tiempo para seleccionar los mejores caballos.

Estará Símaco más agradecido si ayuda al desplazamiento con otros dos caballos de posta, que se distribuirían separadamente para elegir los más selectos de las diferentes provincias. Afirma que el esplendor de los espectáculos con ocasión de la prefectura de su hijo Memio, celebrados en 401, redundará en beneficio de su casa y de la de Hadriano.

En la carta VII.82, enviada a Mesala y datada también en 399, solicita su apoyo para avanzar la gestión a unos amigos íntimos, que viajan a lugares remotos de Hispania, con motivo de comprar caballos para las carreras de carros. Cree prolijo en una carta, recordar lo que debe proporcionar, por eso ha anotado los puntos principales en un anexo adjunto, ya mencionado en cartas anteriores (Ep. VI.2.40.45.48.55.65).

En carta (VII.97) a Flavio Macrobrio Longiniano ${ }^{13}$, del 399, comes privatarum largitiorum, praefectus Romae, le agradece que una misiva de recomendación haya ayudado a sus íntimos amigos, que se dirigían a Hispania a comprar caballos.

La carta VII.105, de la misma fecha, está escrita a Patruino ${ }^{14}$, al que indica que dé gracias a Estilicón por los permisos de posta, considerados como apoyo para la

11 JONES, A.H.M., MARTINDALE, J.R., MORRIS, J., Op. cit., p. 416.

12 JONES, A.H.M., MARTINDALE, J.R., MORRIS, J., Op. cit., p. 572.

13 JONES, A.H.M., MARTINDALE, J.R., MORRIS, J., Op. cit., pp. 686-687.

14 JONES, A.H.M., MARTINDALE, J.R., MORRIS, J., Op. cit., pp. 862-863; 843-844. 
toma de posesión de la prefectura de su hijo. Solicita que se esfuerce para que los enviados a Hispania tengan un viaje rápido, pues se echa encima la toma de posesión de la prefectura de su hijo, y teme que una compra de caballos de carreras y las dificultades del viaje de los animales sean perjudiciales debidos a los límites angustiosos. Le comunica que sobre este asunto ha solicitado ayuda a Estilicón. Añade una instrucción, que espera que apoye, sin no le molesta, para acompañar a los amigos, con cartas dirigidas a los hispanos más influyentes. Símaco estaba muy preocupado por la rápida obtención de los caballos hispanos. Acudió al mismo Estilicón. Envió amigos a Hispania a buscar los caballos, y buscó apoyo en amigos que ayudaran a los enviados.

En carta IX.12, del 398-401, comunica a Perpetuo los espectáculos de la prefectura que su hijo muy pronto celebrará, para la cual ha de preparar caballos de raza para las carreras. Le pide que entre todas las yeguadas de Hispania, que es rica en caballos, escoja diligentemente los caballos más selectos por su raza, y que destaquen por su velocidad. Ha enviado a unos amigos que tardarán en valorar a los animales. Le ruega que preste atención a este asunto y le estará agradecido.

La carta IX.18, de idéntica fecha, está dirigida a una dama de nombre Pompeya. Le comunica que ha enviado a Hispania unos allegados, posiblemente parientes, para comprar caballos para las carreras. En la carta le presenta sus respetos y le pide que se digne escoger todos los caballos de la mejor raza de sus yeguadas para que los parientes los compren a un precio justo. Es la única propietaria de caballos.

La carta IX.19, de la misma fecha, está enviada a Nicómaco Flaviano ${ }^{15}$, consularis Campaniae, prefecto de Roma, procónsul de Asia, y procónsul de Italia, Iliria y África., que tenía yeguadas en Hispania. Menciona la necesidad de obtener caballos para celebrar la prefectura de su hijo, y que ha enviado allegados a obtenerlos de sus yeguadas.

La carta IX.20, del 399, está escrita a Baso, que ya ha recibido otras cartas (I.72; IV.36.38), personaje importante, pero del que se desconocen las magistraturas ejercidas. Le comunica que su hijo, para celebrar la prefectura de Roma, debe disponer de caballos de buena raza para las carreras. Le informa, igualmente, que ha enviado hombres para seleccionar y comprar unos excelentes tiros de caballos. Teme Símaco la llegada del invierno, con la que se impida el viaje de los caballos. Le ruega, si es necesario, que durante los tres o cuatro meses del invierno ordene que les suministren a los animales pastos en sus propiedades, para que lleguen en buen estado, al comienzo de la primavera, a Roma; solicita que ayude a los suyos en la compra de los caballos, si encuentran en Arlés, importante centro comercial, algunos caballos que destaquen por su velocidad y su raza, pues se debe aprovechar la ocasión si en lugares próximos se presenta. Le estará agradecido.

15 MARTINDALE, J.R., The Prosopography of The Late Roman Empire. A.D. 395-527. II, Cambridge 1980 , p. 474. 
La carta IX.21 está enviada al vicario de las Hispanias, de nombre desconocidos. Su fecha es el 399-400. Le informa que, con motivo de los espectáculos organizados con ocasión de la prefectura de su hijo, necesita comprar caballos para los carros, y con este fin ha enviado hombres muy allegados a él a Hispania, para comprar tiro de cuadrigas, elegidos entre los de buena raza entre las yeguadas. Le pide que ayude a los enviados y le declara su agradecimiento.

La carta IX.22, de la misma fecha que la anterior, está escrita a Aureliano, personaje desconocido. Le comunica que ante la proximidad de la prefectura de su hijo, va a enviar a Hispania a algunos de los suyos a comprar tiros de cuadrigas de carreras entre las yeguadas de buena raza. Pide que se les ayude para que hagan con rapidez el trabajo, y que gestione la concesión de los servicios de posta, es decir, autorización, ya mencionada en las cartas I.21; IV.7; VII.105-106. Estas peticiones ya las había solicitado, pero su cuidado en la gestión.

La carta IX.26, fechada entre los años 399-400, está dirigida a Baso. En ella le comunica la satisfacción que tiene al recibir sus cartas y la noticia de que llegará en breve. Para que venga antes, le recuerda que su hijo obtendrá la prefectura el próximo año, 401. Le ha escrito más extensamente por medio de los enviados a Hispania a comprar caballos. Le ruega nuevamente que si las inclemencias del invierno retrasan la llegada de los caballos, están guardados durante unos pocos meses en sus fincas, y que partan a Roma a comienzos de la primavera.

La carta IX.23, del 398-401, está enviada a Marcelo, personaje desconocido, pero que contaba con un gran patrimonio en Hispania, por lo que se supone que residía aquí. Se ha enterado que se encontraba en la casa de sus antepasados. Por esta razón se ha dirigido de nuevo a él. Le pide que para la fiesta de la prefectura de su hijo añada unos tiros de cuadriga de raza, entresacados los mejores procedente sde muchas diferentes yeguadas. Solicita una carta de recomendación para los empleados que van a comprar los caballos. El tono de la carta indica una gran amistad y confianza con Marcelo.

La carta IX.25, fechada en 398-399, se envió a Vincencio, prefecto del pretorio de las Galias en 397-400 y cónsul en 400. Le agradece el envío de sus escritos. Solicita de él que, con una carta y con asignación de un asistente, ayude a las tareas de los suyos, enviados a comprar tiros de cuadrigas de carreras para los espectáculos organizados con motivo de la prefectura de su hijo. Solicita de él que confirme por carta las autorizaciones de requisa de caballos emitida por Flavio Malio Teodoro, para que no languidezca la autoridad del beneficio por el cambio de gobernador. Le estará, si alcanza la petición, muy agradecido.

\section{MOSAICOS HISPANOS DE LA TARDA ANTIGÜEDAD CON CABALLOS}

Los mosaicos hispanos del Bajo Imperio confirman y completan los datos de Símaco referentes a Hispania. 


\section{MARCAS DE YEGUADAS}

El tema ha sido bien estudiado por G. López Monteagudo'16, a la que seguimos.

Marcas de propietarios se han interpretado como marcas de la ganadería, , p.e. palma en los caballos, Leneus (Torre de Palma), y el naufragium de Barcelona; el skyphos en Delius y Pafius (Mérida) y en el yugal compañero de Inluminator (Mérida); cerdo en Inacus (Torre de Palma), etc. Algunos de estos signos son de carácter indiscutiblemente báquico, lo que va bien con el contexto de varios mosaicos (p.e. el skyphos que aparece en varios mosaicos de Mérida) y con ciertos nombres que, como Botrocales (Barcelona) o Leneus (Torre de Palma, en esta ocasión además el caballo lleva una palma), tienen una connotación báquica.

De todos estos símbolos el más frecuente es la palma, que aparece en mosaicos hispanos (Barcelona, Torre de Palma), y que, si se admite ser marca de ganadería, indicaría la cuadra común de caballos documentados en distintas regiones del imperio. Otro tanto podría decirse del skyphos que se repite en varios mosaicos emeritenses, acompañando a los caballos Delius y Paphius, así como al yugal compañero de Inluminator. Sin embargo, teniendo en cuente el valor profiláctico de estos signos en otros mosaicos, siempre con un significado de prosperidad y de buena suerte, es posible que no se trate de marcas de ganadería sino de símbolos de victoria o de buen augurio, lo que va muy bien con los caballos de competición y de caza, cuyo objetivo final es siempre la consecución del éxito, tanto en el circo como en el campo. Además, estos caballos suelen llevar sobre su cabeza palmas, símbolo indiscutible de triunfo, documentado en numerosos mosaicos de caza y de circo, y a veces van acompañados de Victorias aladas que llevan la palma en la mano como trofeo al caballo ganador: Narcissus y Delius (Mérida). Otros signos de buena suerte, como las hojas de hiedra, tan frecuente en la musivaria hispana, acompañan también a algunos caballos.

\section{NOMBRES DE LOS PROPIETARIOS}

Ciertos animales llevan sobre la grupa o el costado, o sobre otras partes del cuerpo, el nombre completo o las iniciales del propietario: Concordi y Niceti (Barcelona), Getuli, ECD, TA y FU (Mérida), C (Dueñas), LC (Centelles). A veces es difícil distinguir si se trata del nombre del caballo o del propietario, como sucede por ejemplo con las inscripciones que acompañan a estos últimos que, según Ennaïfer, responden a los nombres de los dueños y no a los caballos, y realmente la repetición de las letras MUF en tres de los cuadros, o de Anni en dos de ellos parecen hacer clara referencia al nombre del propietario. Por su parte, Salomonson opina que los nombres de los caballos están sugeridos por los personajes enigmáticos que los acompañan, los cuales vienen a ser «imágenes parlantes» según este au-

16 Op. cit., pp. 981-983. 
tor. Otro tanto podría decirse acerca de las inscripciones que aparecen en el mosaico de Mérida con representación de la cuadriga conducida por la Victoria, que se encuentran tanto sobre los caballos, como en el cuello y en la grupa. Criadores hispanos de caballos serían Concordi, Niceti, ECD, FU, C y LC, mientras que Getuli habría que colocarlo entre los criadores africanos.

\section{EXPORTACIÓN DE CABALLOS HISPANOS EN EL S. II}

Los datos aportados por los epígrafes que aparecen en la musivaria hispana se complementan con la importante inscripción del s. II descubierta en Roma (CIL VI 10056), en donde un auriga anónimo menciona una lista de 32 caballos de procedencia hispana, con los que ha triunfado 1.378 veces, especificando al lado del nombre de cada caballo, el color del mismo, el nombre del propietario y el número de victorias con él obtenidas. Algunos nombres, como Notato, Amores, Nórdico y Perdice se repiten como nombres de caballos hispanos y africanos. Esta inscripción indica la exportación de caballos hispanos a Roma, ya en el s. II.

La repetición de algunos nombres de caballos en varios mosaicos hispanos y norteafricano: Amor, Botrocales, ...ens, Eufrata, Luxuriosus, Narcissus, Pantaracus, Pelops, Scolasticus, puede interpretarse de dos formas. Existe la posibilidad de que se trate del mismo caballo, el cual se había hecho famoso a través de sus repetidas victorias en distintos circos del Imperio. Más probable es que los nombres se repitan en diferentes siglos, pues la fecha de los mosaicos es diferente.

\section{RETRATOS DE CABALLOS Y DE AURIGAS}

Como retratos de caballos famosos, G. López Monteagudo considera los cinco caballos (fig. 1) de la villa constantiniana de Torre de Palma (Lusitania), cada uno dentro de un cuadro, colocados de perfil o de tres cuartos, engalanados con palmas y collares, acompañados de sus respectivos nombres: Hiberus, Leneus, Inacus, Pelops y Lenobatis. Leneus va marcado con una palma e Icarus con un cerdo. El nombre de Pelops se repte en el final de la cuadriga vencedora del mosaico circense de Barcelona. Posiblemente son también retratos de caballos y de aurigas las dos cuadrigas del mosaico emeritense con los aurigas Marcianus y Paulus (figs. 2-3). Los dos caballos del mosaico emeritense con cuadriga, con el auriga Narcisus Delficus (fig. 4), conducida por Niké, el caballo Pafius y el cazador Marianus (fig. 5) de Augusta Emérita , y caballo Amoris de la villa de Dueñas (fig. 6); la cuadriga de El Pomar, Jerez de los Caballeros, con inscripción borrosa. 

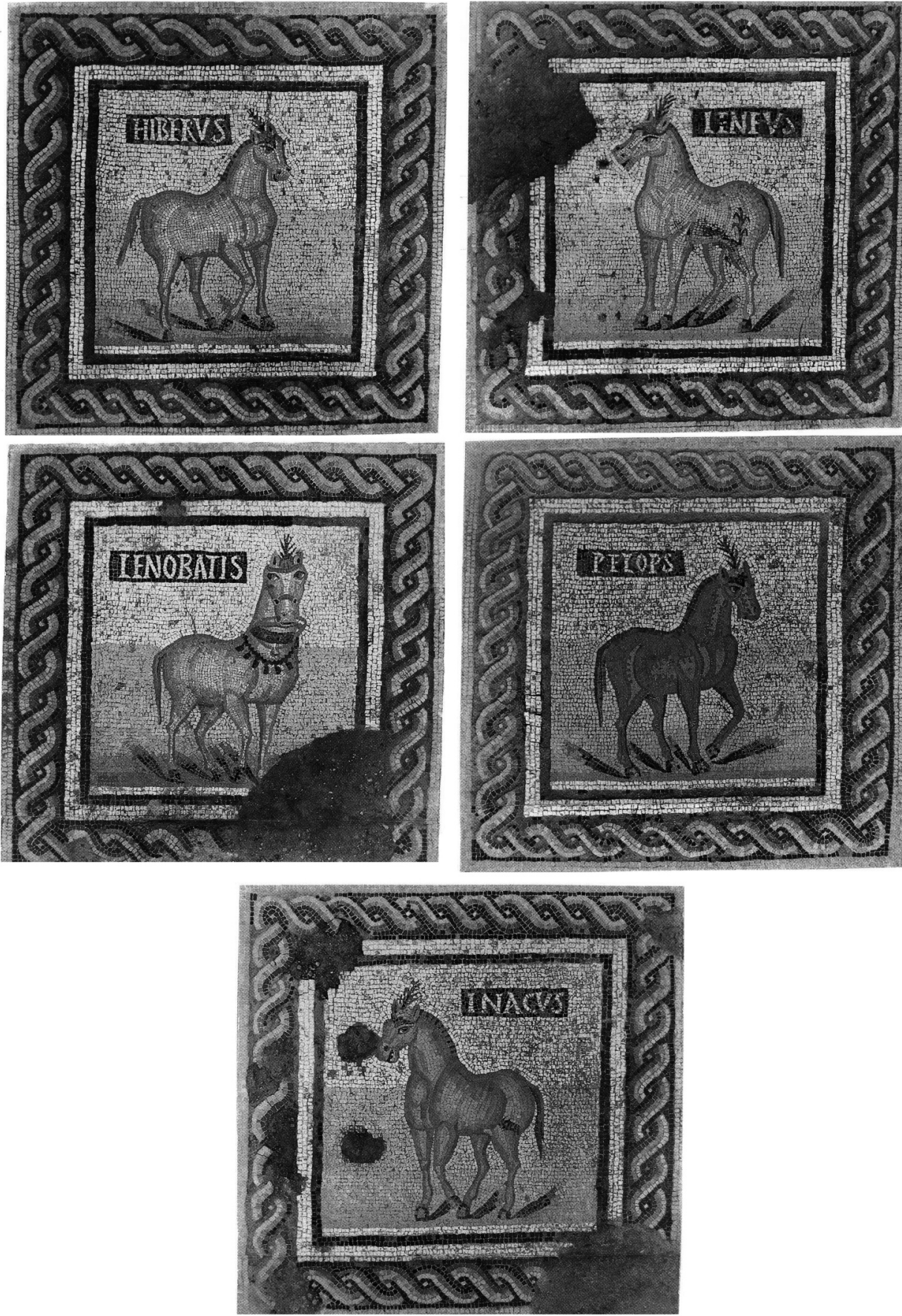

Fig. 1. Mosaico de Torre de Palma. Según Internet. 


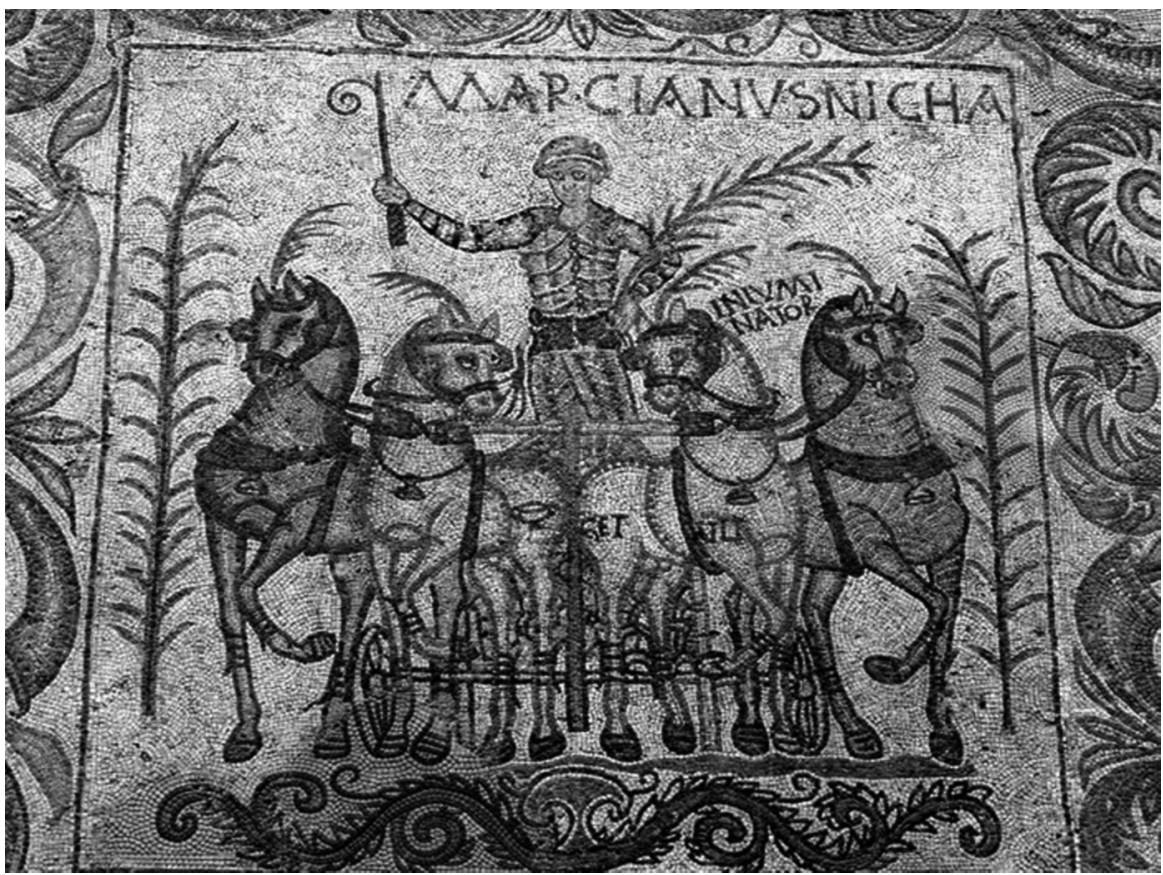

Fig. 2. Mosaico con la cuadriga vencedora del auriga Marcianus. Augusta Emérita. Según Internet.

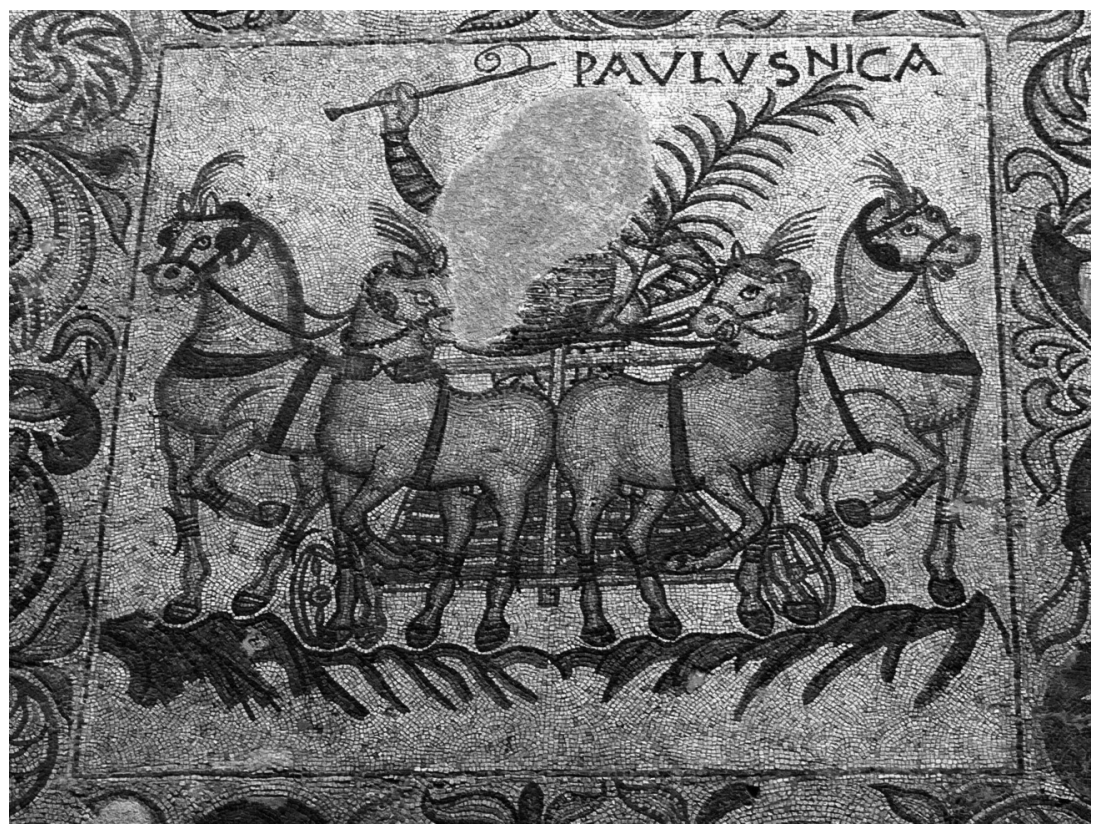

Fig. 3. Mosaico con la cuadriga vencedora del auriga Paulus. Augusta Emérita. Según Internet. 


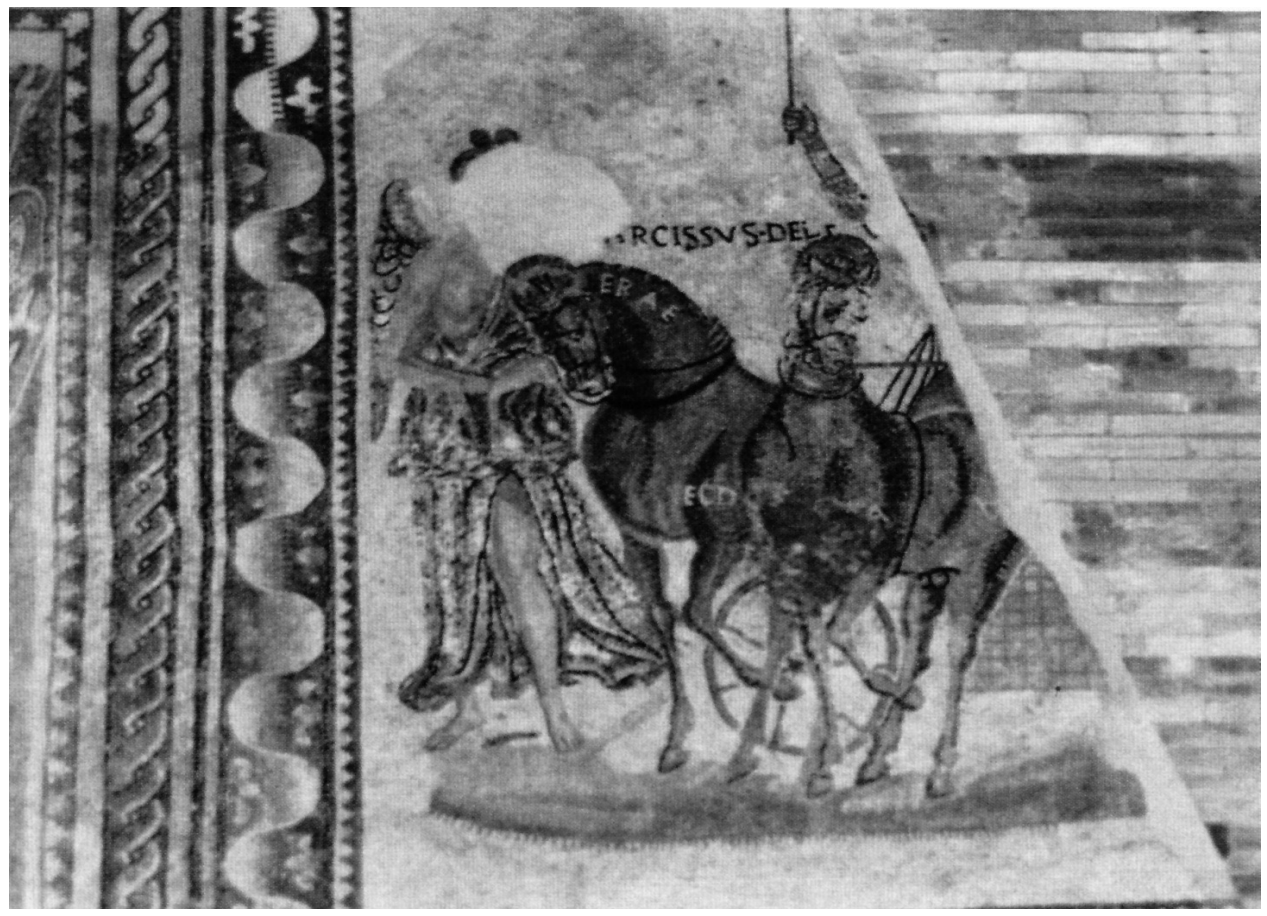

Fig. 4. Mosaico con la cuadriga vencedora del auriga Narcisus Délficus. Augusta Emérita. Según Internet.

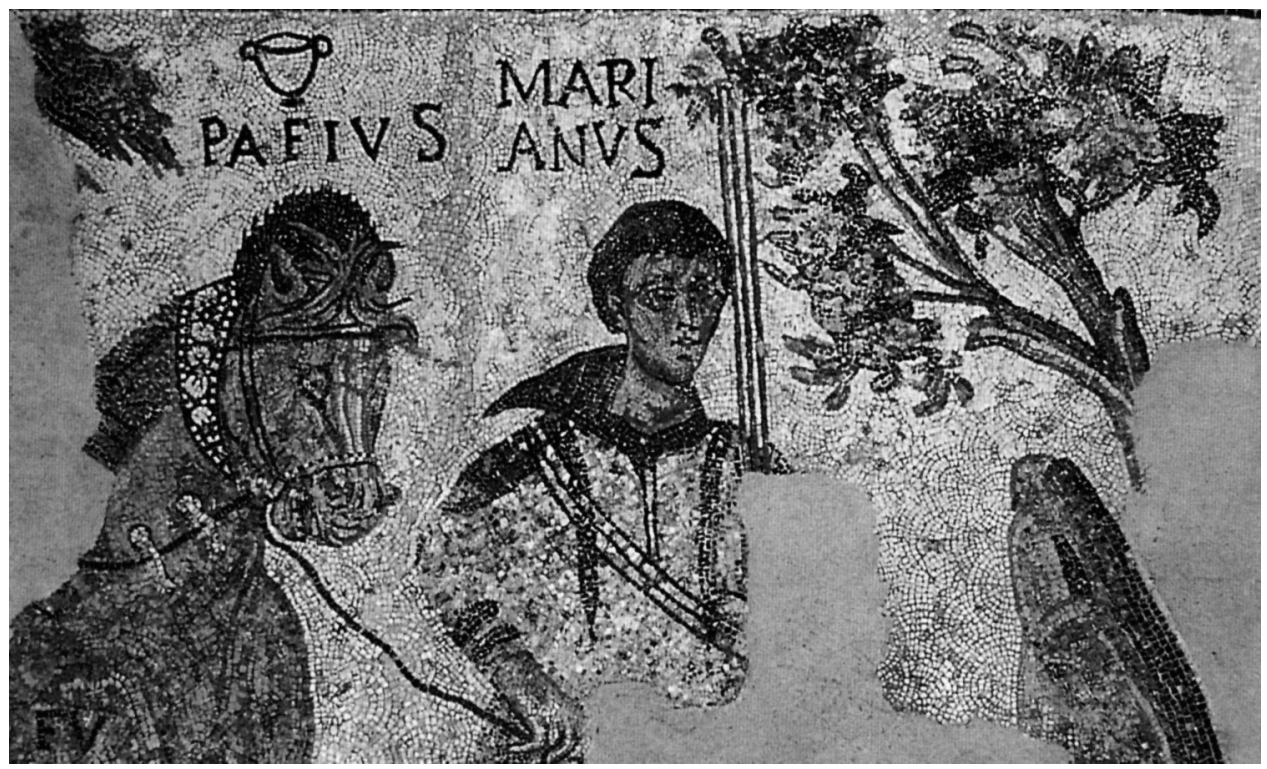

Fig. 5. Mosaico del cazador Marianus. Augusta Emérita. Según Internet. 


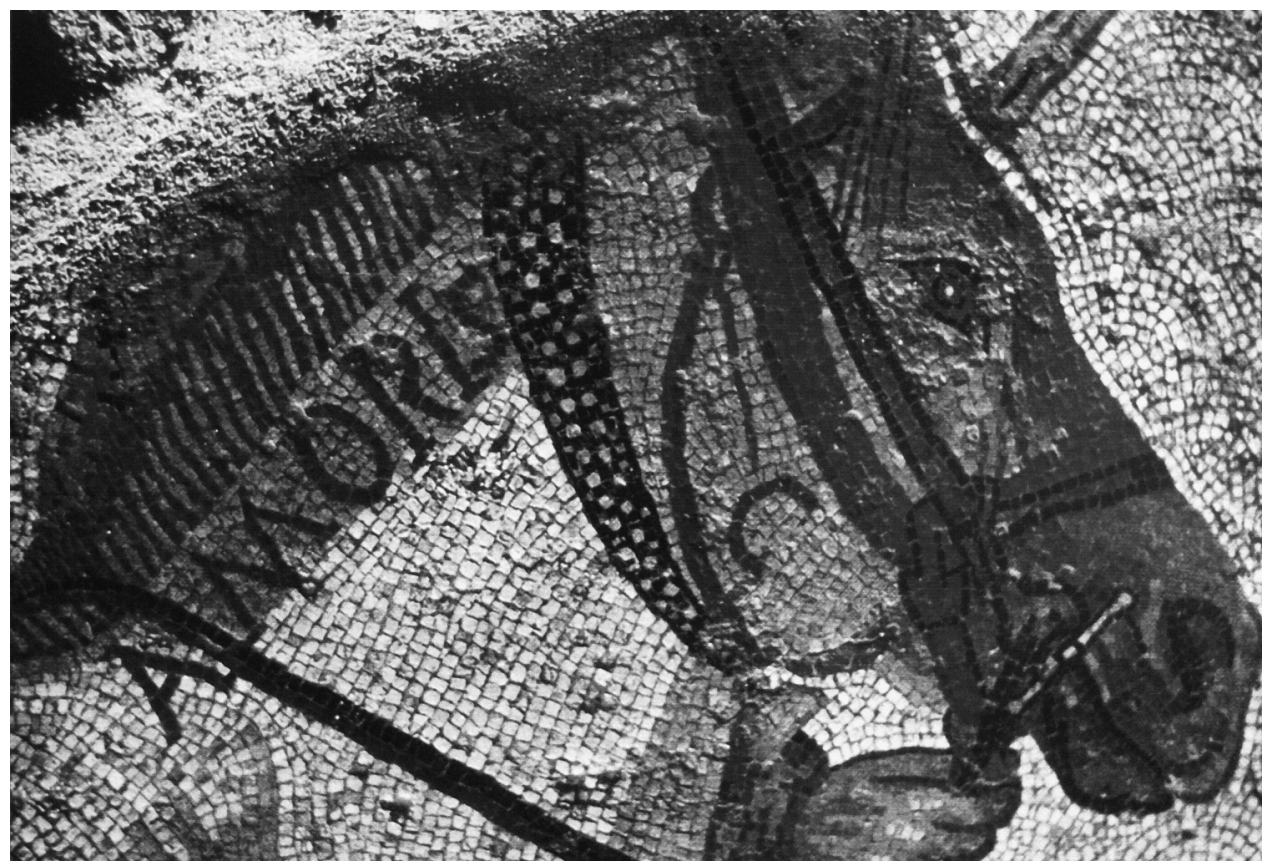

Fig. 6. Mosaico con el caballo Amoris. Dueñas. Según G. López Monteagudo.

\section{NOMBRES DE CABALLOS}

Los caballos hispanos corriendo en el circo, van frecuentemente acompañados de sus respectivos nombres.

Los nombres de los caballos del mosaico circense de Barcelona, son los siguientes, según J. Gómez Pallarés ${ }^{17}$ (figs. 7-8):

$\begin{array}{ll}\text { a. } & \text { I II I } \\ & \text { IIII } \\ & \text { W T } \\ & \text { D G O } \\ \text { q D }\end{array}$

17 PALLARÉS, J.G., Edición y comentario de las inscripciones sobre mosaicos de Hispania. Inscripciones no cristianas, Roma 1997, pp. 49-54, láms. 7-9; BLÁZQUEZ, J.M., «El Circo Máximo de Roma y los mosaicos circenses hispanos de Barcelona, Gerona e Itálica", NOGALES, T., SÁNCHEZ PALENCIA, F.J. (eds.), El circo en Hispania Romana, Madrid 2001, pp. 197-215; DARDER, M., De nominibus equorum circensium. Pars Occidentis, Barcelona 1996, pp. 267-290. 
b. ERIDANVS

c.1 Botrocal[-- (herdera?)]

c.2 ISCOLASTICVS (herdera?)

c.3 REGNATOR (herdera?)

c.4 FAMOSVS (herdera?)

d.1 PYRIPINVS

d.3 EVFRATA

d.4 Eustolus

e.1 CONCO[RDI]

e.2 CONC[ORDI]

e.3 CONCO[RDI]

f. 1 [-] - ISVS

f.2 [--]IVS

f.3 [--]VS

f.4 [--]VOR

g.1 NICET[I]

g.2 CONCOR(vacat)DI

g. 3 CONC[OR] (vacat)DI

h.1 ERIdanus

h.2 ISPVMEus

h.3 PELOPS

h.4 LVCXURiosus

i. NICETI 


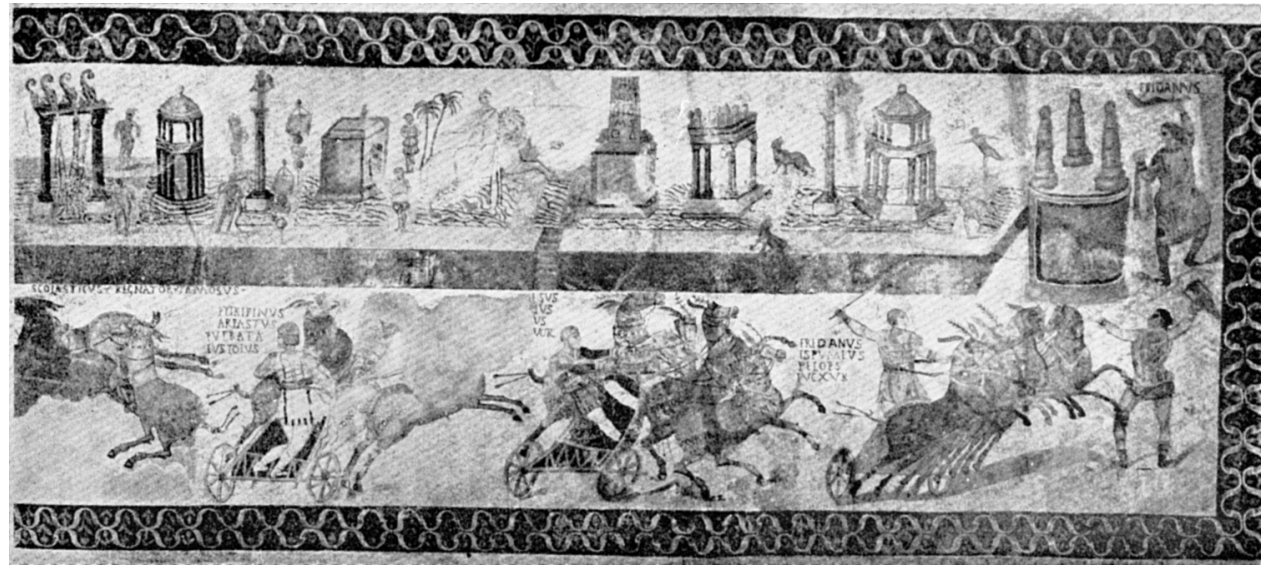

Fig. 7. Mosaico circense de Barcelona. Detalle. Según Internet.

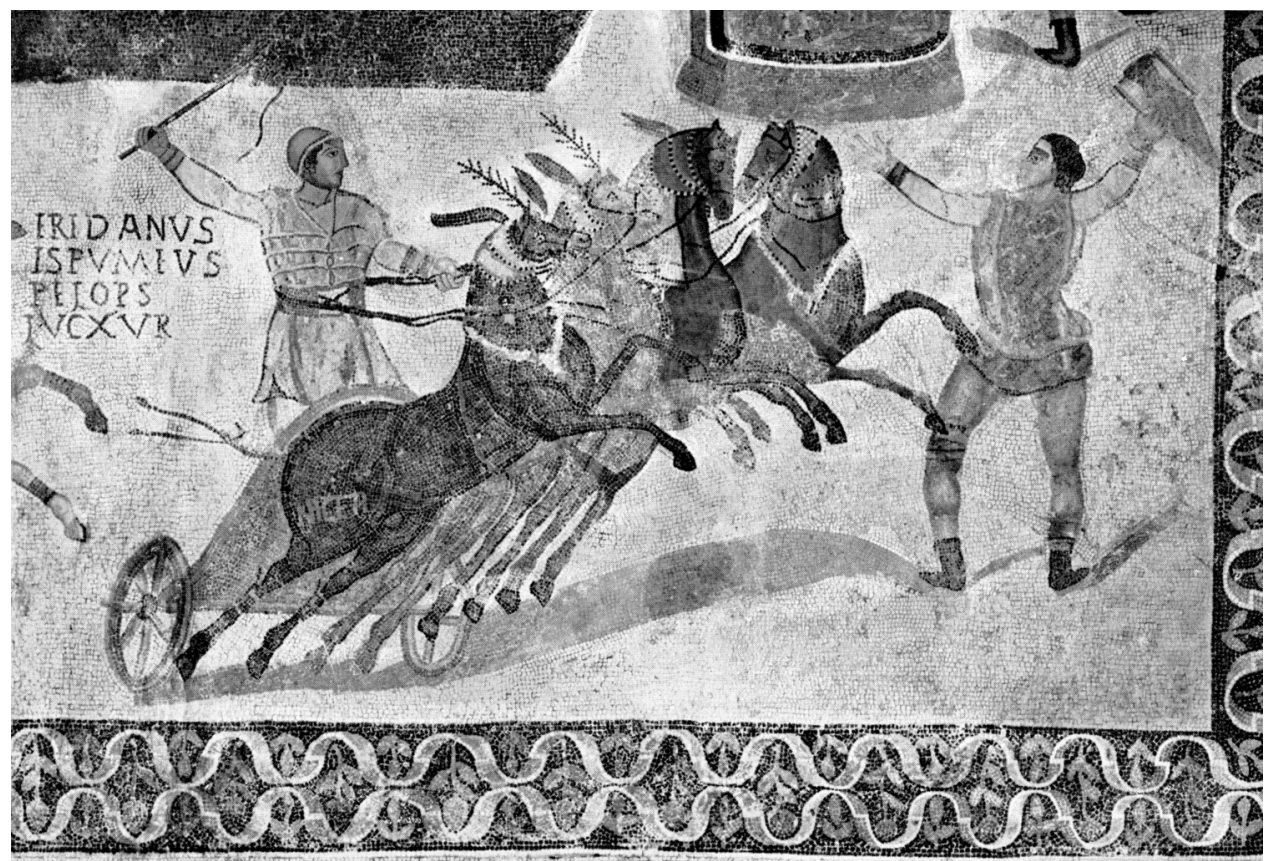

Fig. 8. Mosaico de Barcelona. Detalle. Según Internet. 
Los del mosaico de los aurigas de la villa de Bell-Lloch ${ }^{18}$ (figs. 9-15), ambos datados hacia mediados del s. IV, son:

\section{a. 1 FILORO}

MVS

a.2 PANTARACVS

b. 1 Torax

b.2 POLYSTE[F]

ANVS

c.1 CALIMORfVS

c.2 PATINI(vacat)CVS

d.1 LIMENIus

d.2 FV(vacat)PLIVm

e. CECILIANVS . FICET

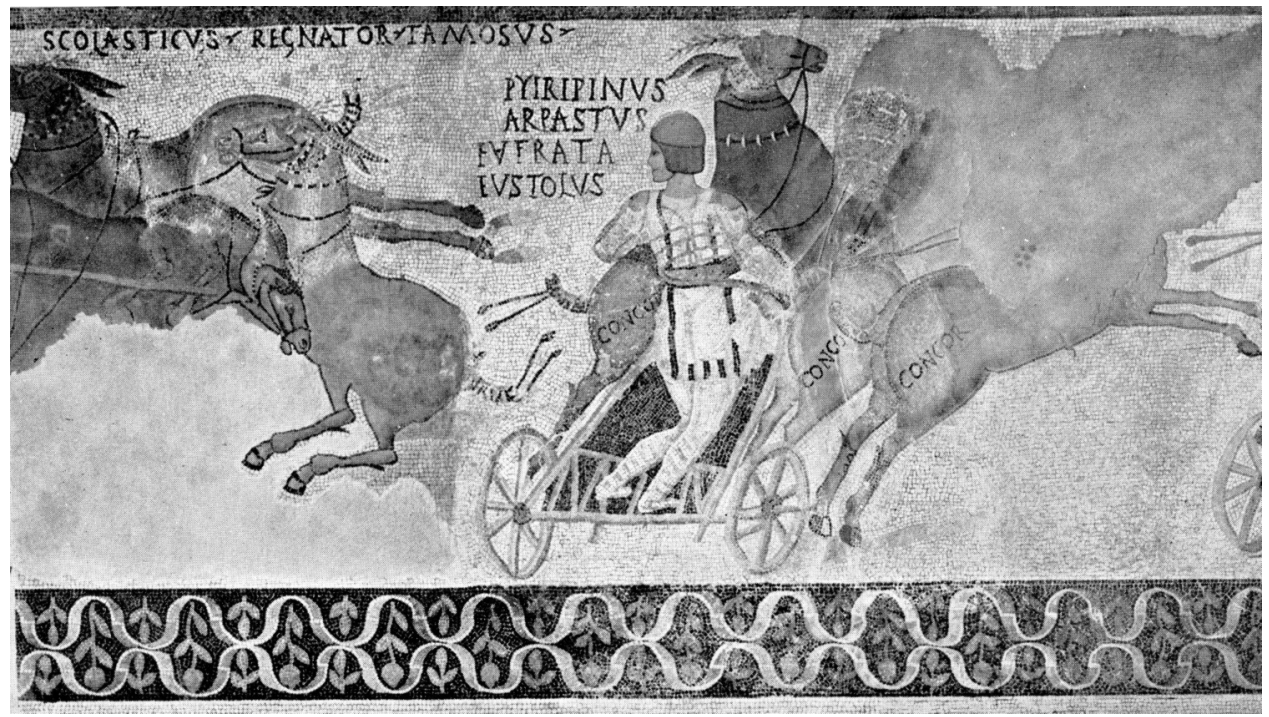

Fig. 9. Mosaico de Barcelona. Detalle. Según Internet.

18 PALLARÉS, J.G., Op. cit., pp. 96-99; BLÁZQUEZ, J.M., «Nombres de aurigas, de possessores, de cazadores y de perros en mosaicos de Hispania y de África», L'Africa Romana IX, 1992, pp. 953-964. 


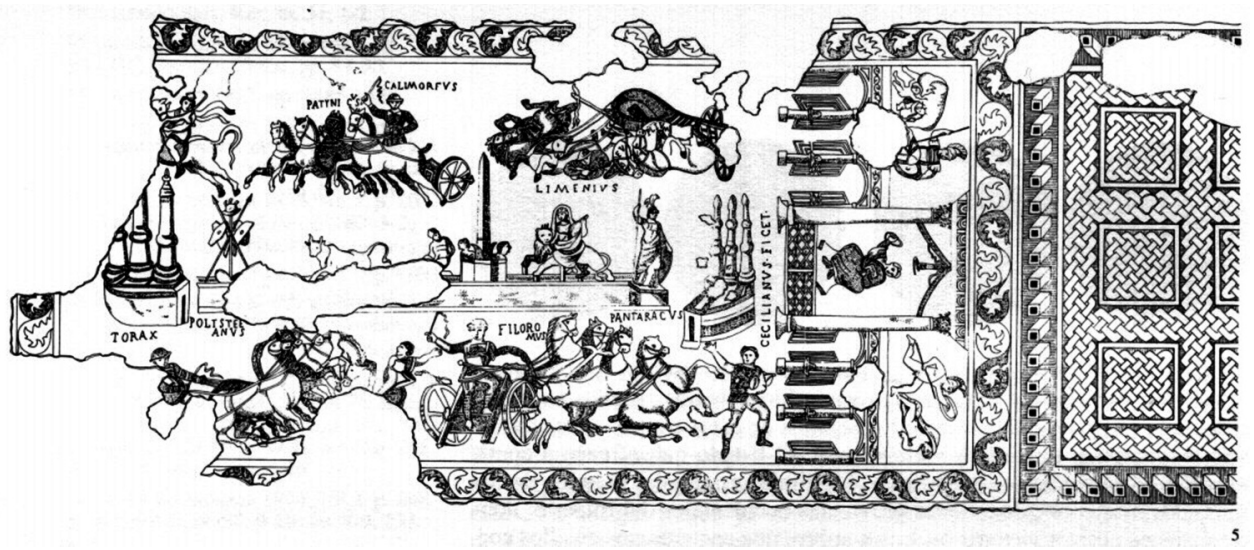

Fig. 10. Mosaico circense de la villa de Bell-Lloch. Detalle. Según Internet.

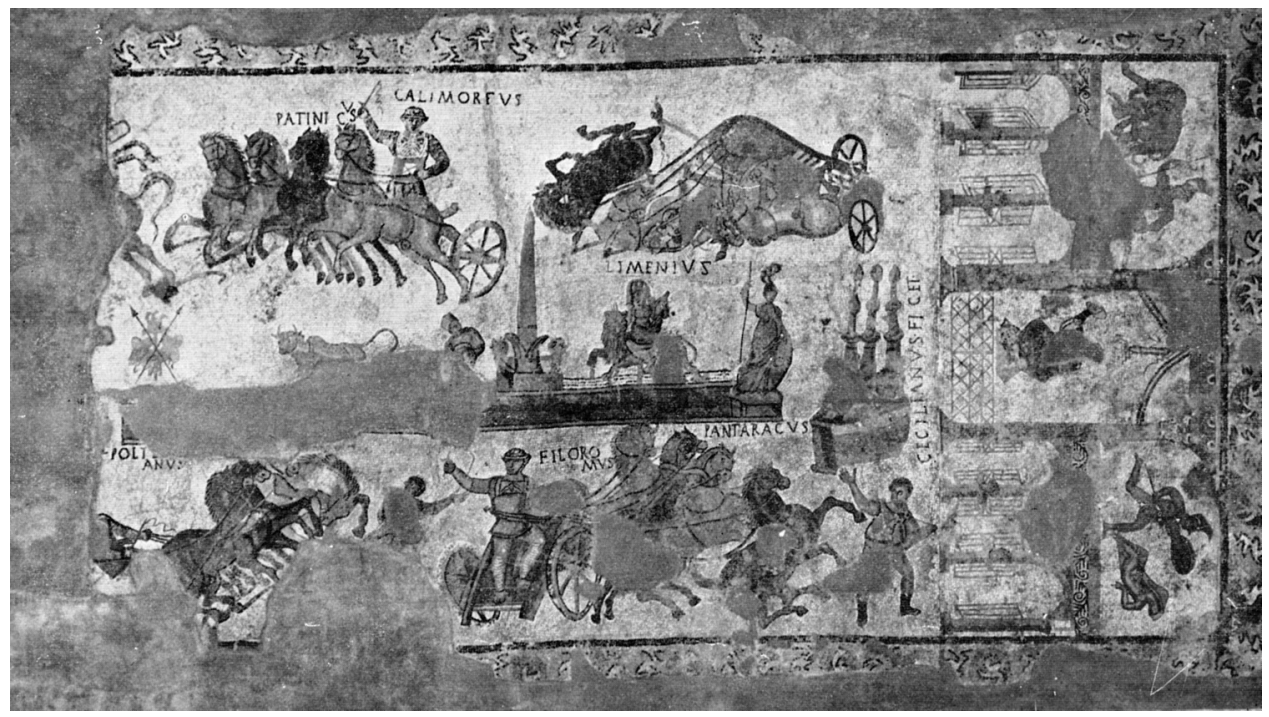

Fig. 11. Mosaico circense de la villa de Bell-Lloch. Según Internet.

La profesión de auriga está condenada por los cristianos en el Concilio de Elvira, a comienzos del s. IV, canon LXII, pues los espectáculos de teatro, anfiteatro y circo eran rituales religiosos en honor de la Triada Capitolina, Júpiter, 


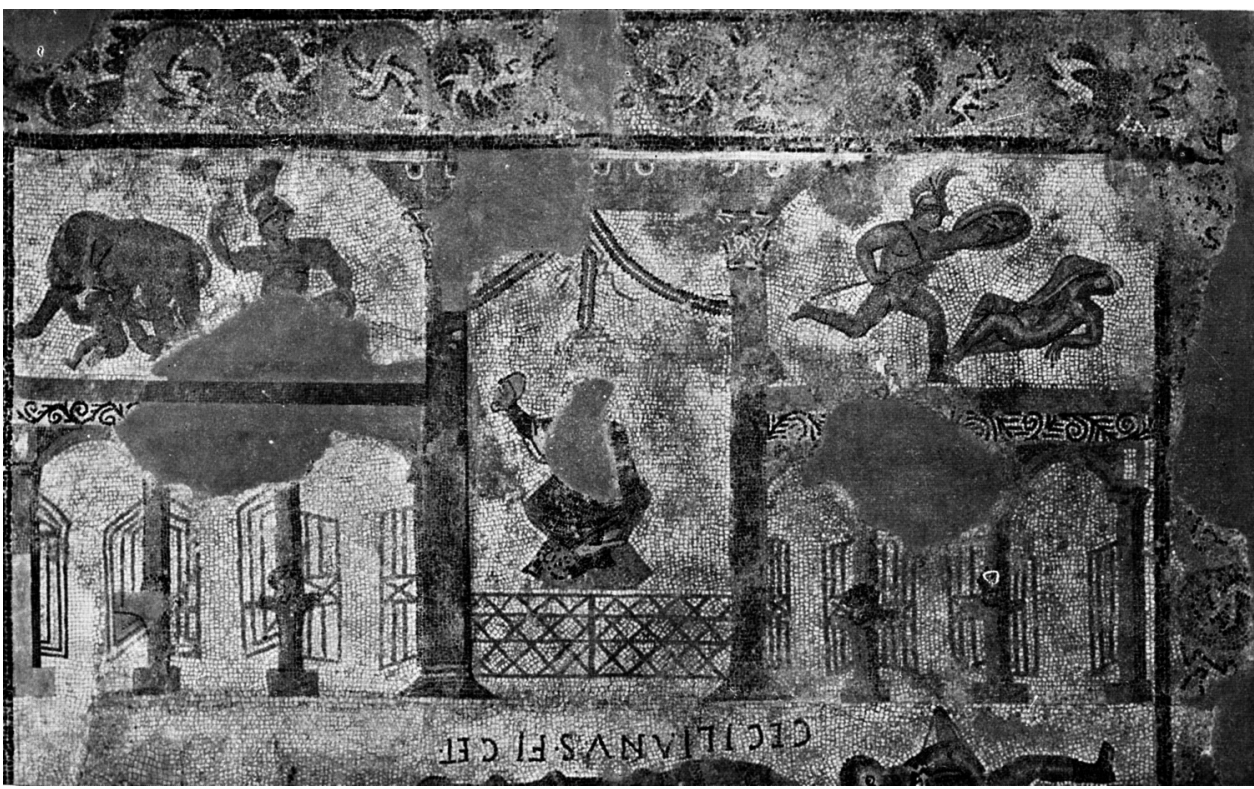

Fig. 12. Mosaico circense de villa de Bell-Lloch. Canceles y Tribunal. Mitos: La loba y los gemelos y Marte. Marte y Rea Silvia. Según A. Balil.

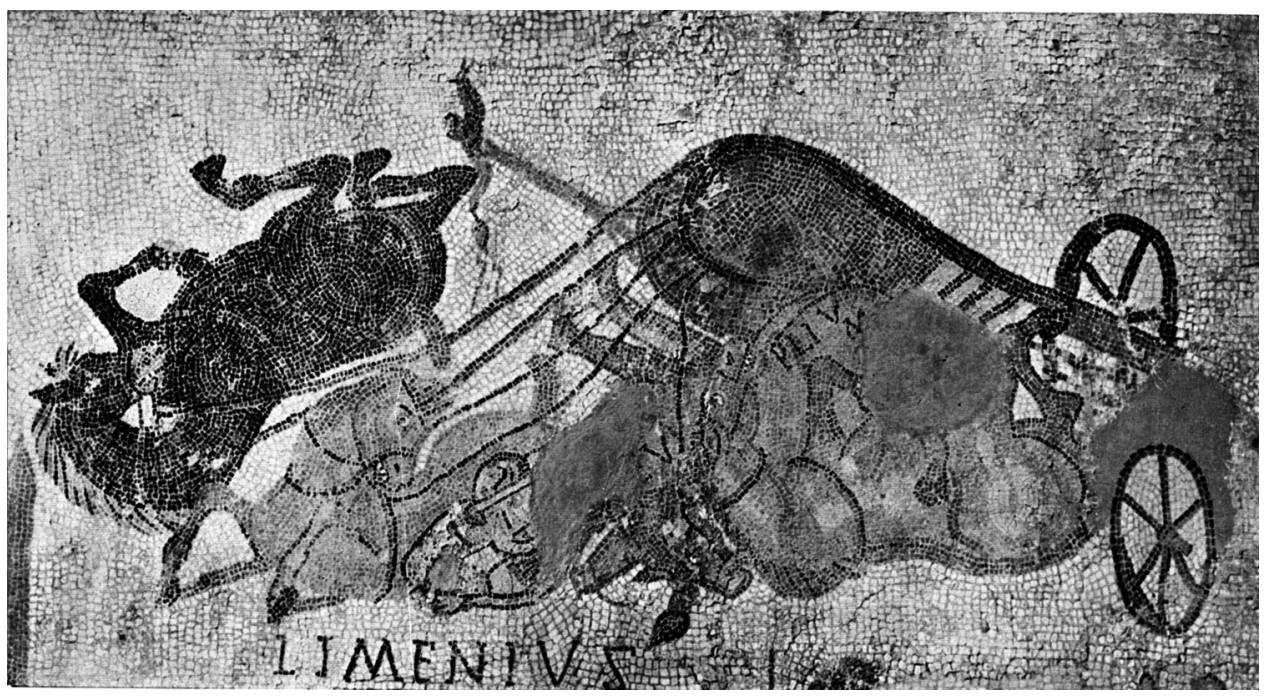

Fig. 13. Mosaico circense de la villa de Bell-Lloch. Naufragium. Auriga Limenius, de la facción prasina. Según Internet. 


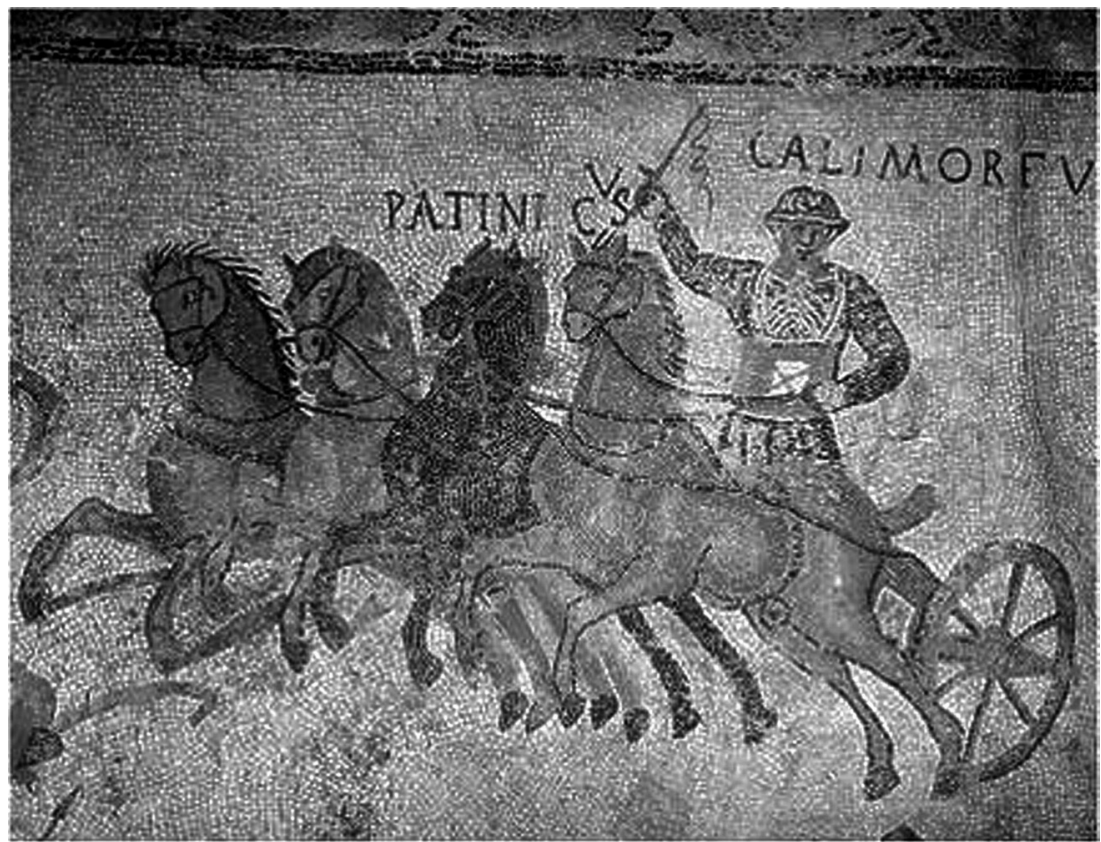

Fig. 14. Mosaico circense de la villa de Bell-Lloch. Auriga Calimorius, de la facción véneta. Según Internet.

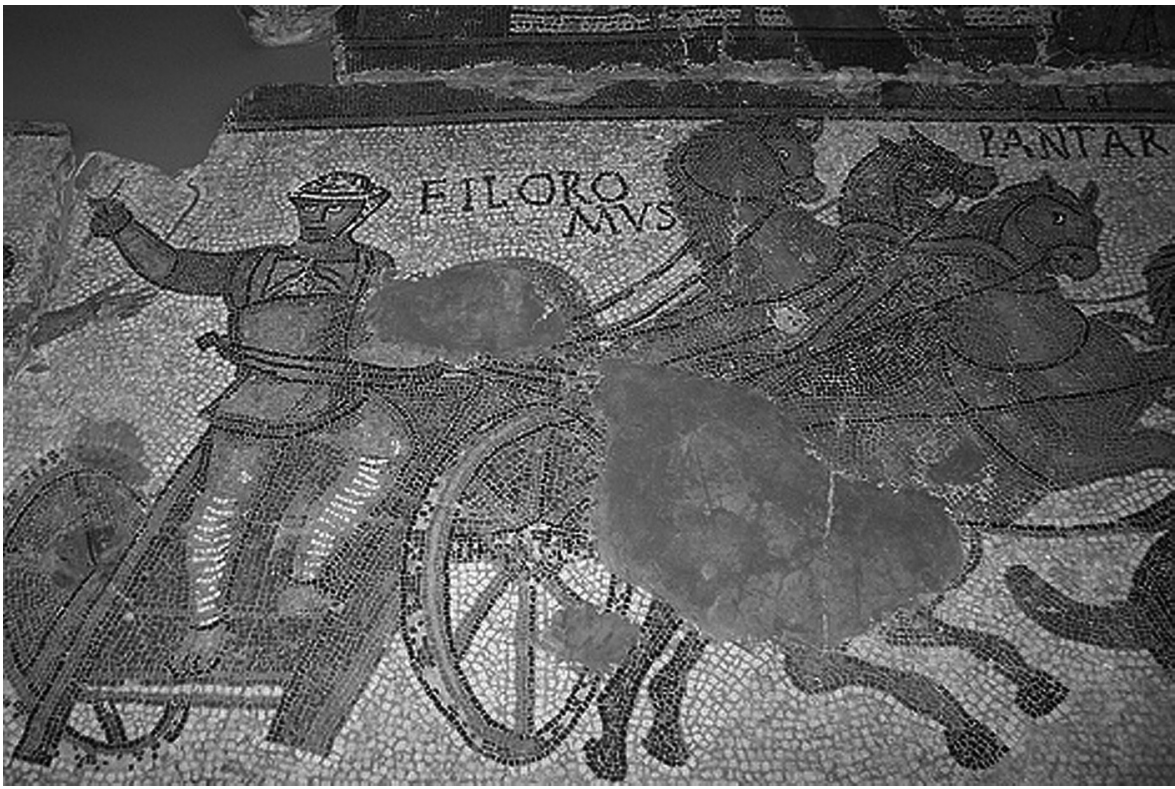

Fig. 15. Mosaico circense de la villa de Bell-Lloch. Auriga Filoromus, de la facción blanca. Según Internet. 
Minerva y Juno, y los costeaban los duunviros y ediles al comienzo de ejercer el cargo, según indica la Ley de la fundación de la colonia Urso, del año 44 a.C., cap. 70, al igual que en Roma. Por este carácter sacro de los juegos, los autores cristianos arremeten contra ellos, como Novaciano, s. III, en su De spectaculis; Tertuliano, finales del s. II a las primeras décadas del s. III, en su De spectaculis; Juan Crisóstomo, en su sermón Contra los juegos circenses y el teatro, del año 399, porque el Viernes Santo se celebraban carreras de carros; Salviano de Marsella, en su De gubernatione Dei, del 440-450, todavía en época tan avanzada el sacerdote marsellés tiene conciencia del carácter sagrado de los espectáculos, que se abrían con una procesión de imágenes sagradas y otras estaban encima de la spina del circo, como Cibeles sobre león y Atenea en el mosaico de Bell-Lloch, y en el de Barcelona, estatuas de Hércules y de Apolo.

\section{LOS CIRCOS EN HISPANIA}

La importancia de los espectáculos circenses ${ }^{19}$ en la Hispania del Bajo Imperio queda bien patente en la restauración de los mismos efectuada entre los años 337 y 340, por Constantino II, por Constancio II y por Constante, los Augustos hijos de Constantino.

En los mosaicos del Bajo Imperio son frecuentes las escenas que representan carreras de carros o caballos de raza. G. López Monteagudo menciona los siguientes: Bell-Lloch, Gerona; Itálica, con espectáculo de carros (fig. 16); Paredas (Sevilla) 8fig. 17); El Val (Alcalá de Henares); Mérida (cinco representaciones de cuadrigas, dos en pintura) (figs. 18-19); Jerez de los Caballeros (Badajoz); Itálica (dos) (fig. 20); Jerez de la Frontera (dos); Torre de Palma; Aguilafuente e Itálica; Dueñas, Itálica, Mérida (dos) y El Pomar.

Los caballos de la cacería de Centelles, posible tumba del hijo de Constantino I, de mediados del s. IV, representan probablemente a caballos hispanos con su marca $^{20}$ (figs. 21-23).

19 HUMPHEY, J.H., Roman Circenses, Londres 1986, pp. 337 ss.; NOGALES, T., SÁNCHEZ PALENCIA, J. (eds.), op. cit.; LÓPEZ MONTEAGUDO, G., «Mosaicos romanos de circo y anfiteatro», VI Coloquio Internacional sobre mosaico antiguo. Palencia-Mérida 1990, Guadalajara 1994, pp. 343-358.

Sobre el circo en general: DUNBABIN, K.M.D., The Mosaics of Roman North Africa. Studies in Iconography and Patronage, Oxford 1978, pp. 88-108. Los mosaicos emeritenses de Marcelus, Paulus, y la pintura y el mosaico de Pomar, siguen modelos bien documentados en el Imperio Romano (DUNBABIN, K.M.D., «The Victorious Charioteer on Mosaics and Related Monument», ARA 86, 1982, pp. 65-89.

Otros espectáculos: ÁLVAREZ, J.M. (ed.), El teatro en la Hispania Romana, Madrid-Badajoz 1981; ÁlVAREZ, J.M., NAVASCUES, E., El anfiteatro en la Hispania Romana, Mérida 1994.

20 SCHUNK, H., Die Mosaikkupel von Centelles, Maguncia 1988, pp. 20-26, lám. 37 b. 


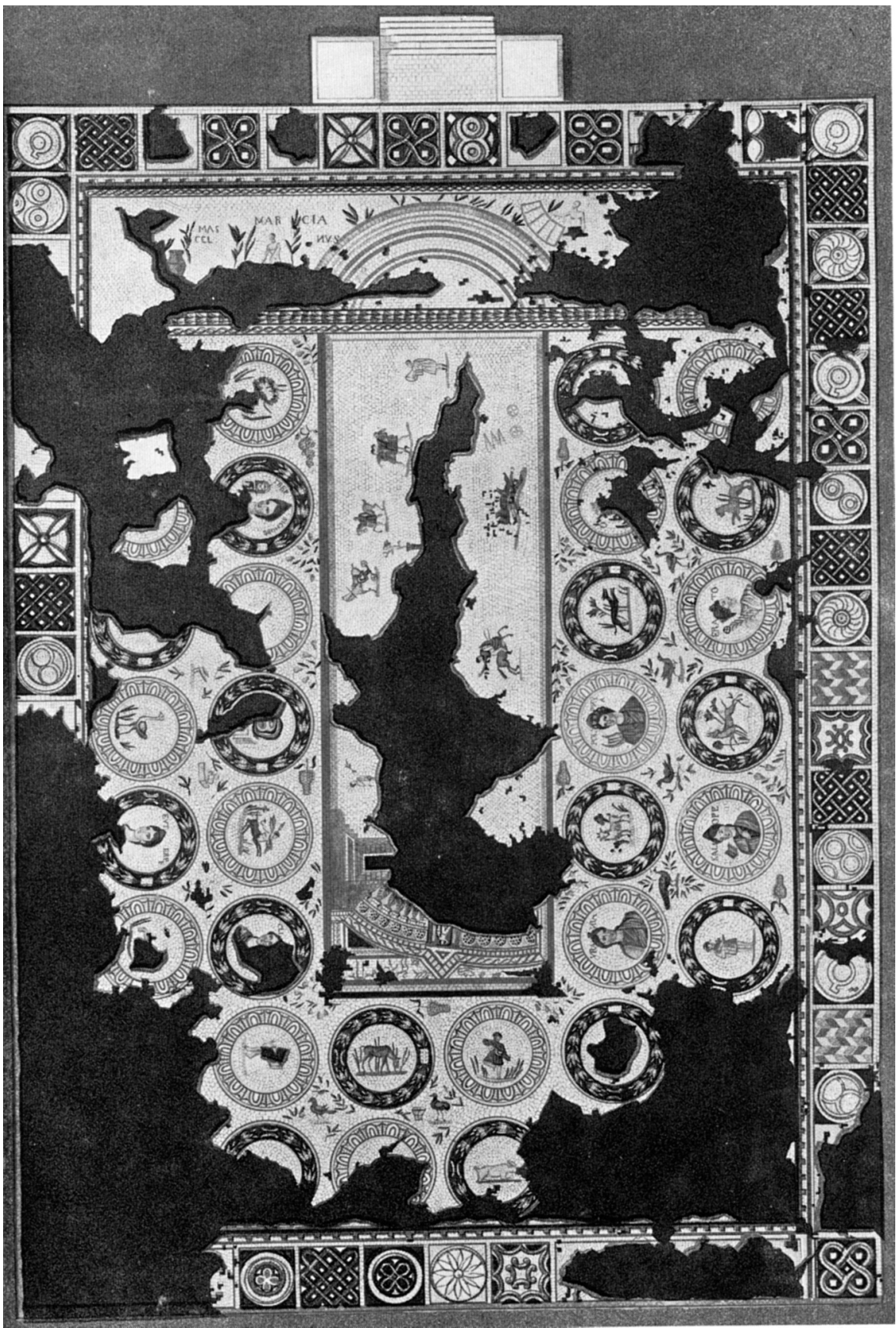

Fig. 16. Mosaico circense de Itálica. Perdida Eo. Según Internet. 


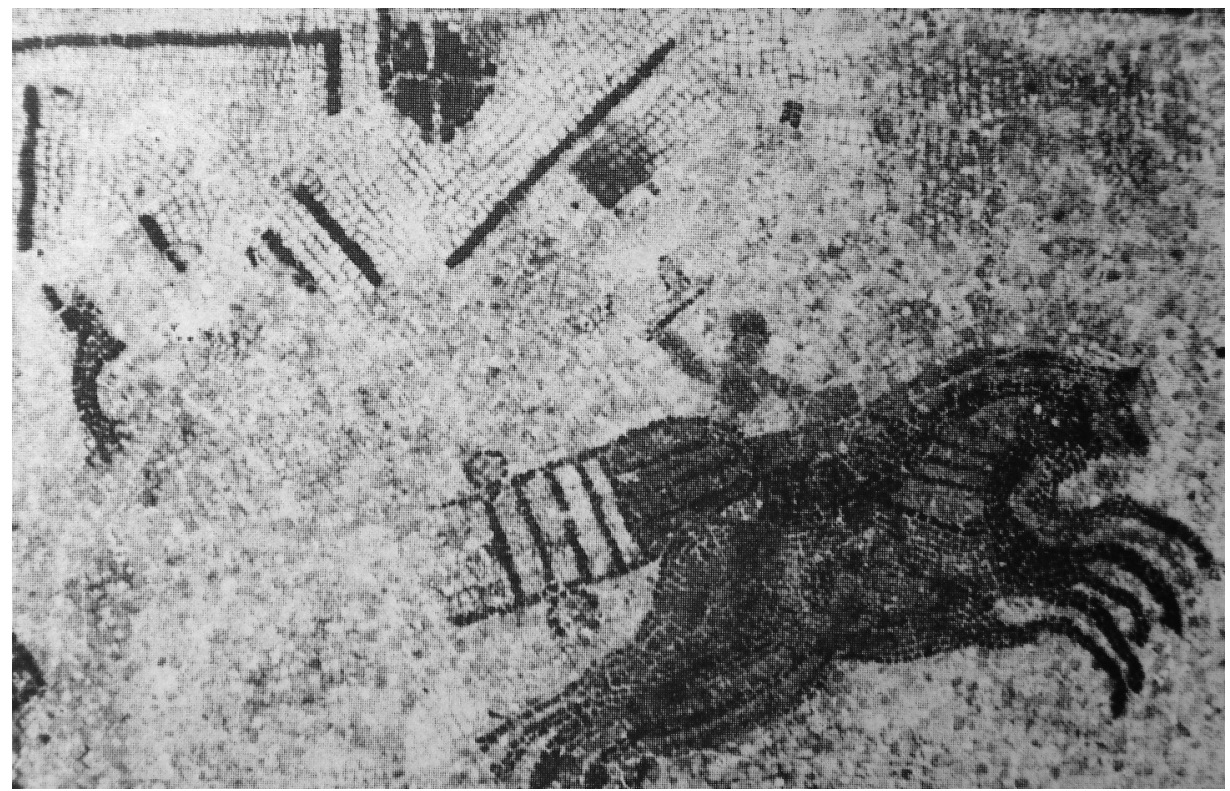

Fig. 17. Mosaico circense de Paradas. Detalle. Cuadriga corriendo. Según Internet.

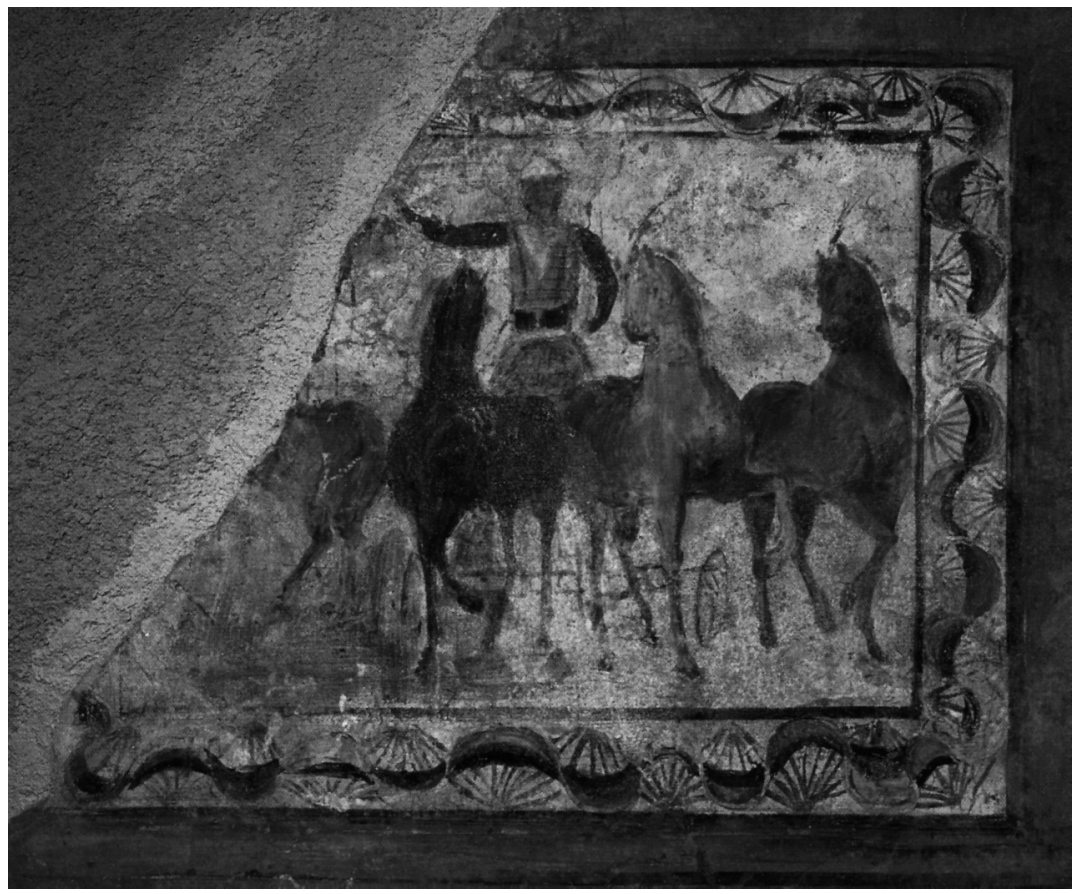

Fig. 18. Cuadriga vencedora. Pintura. Augusta Emérita. Según Internet. 


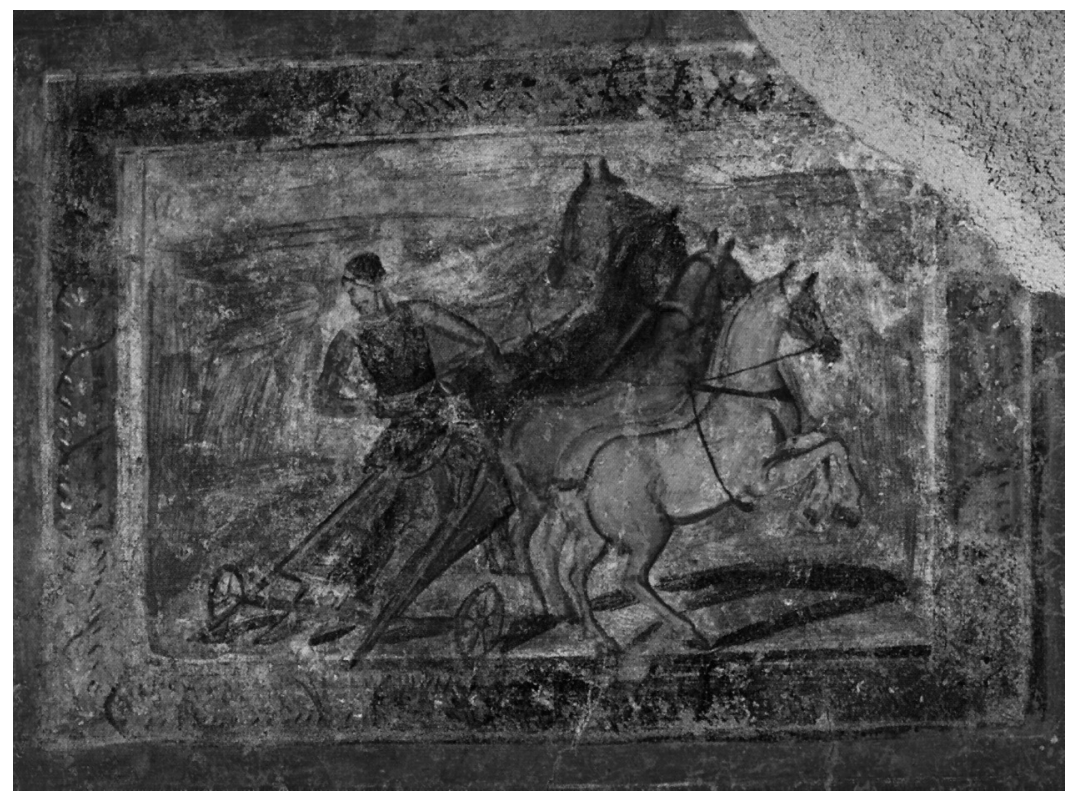

Fig. 19. Cuadriga corriendo. Pintura. Augusta Emérita. Según Internet.

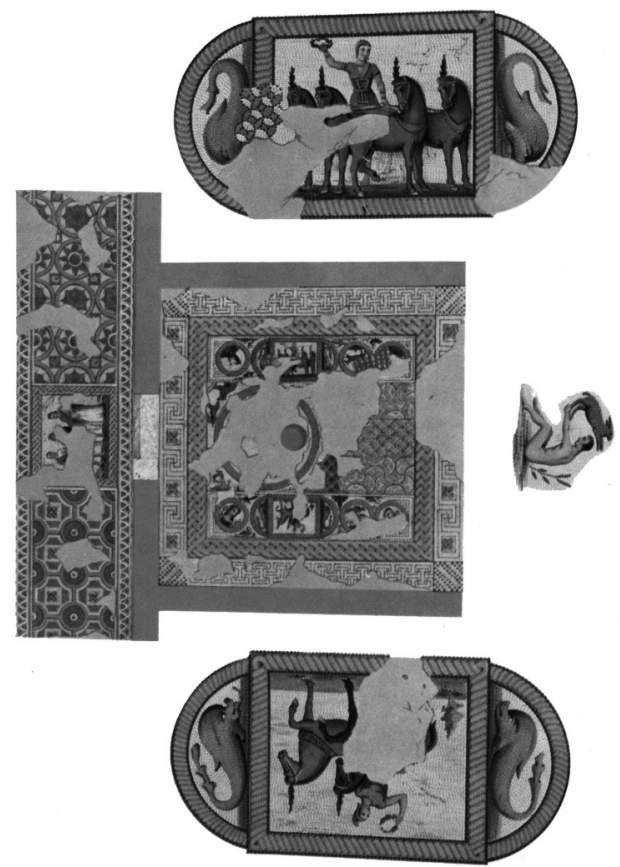

Fig. 20. Mosaico circense de Itálica con cuadrigas y biga. Perdido. Según Internet. 


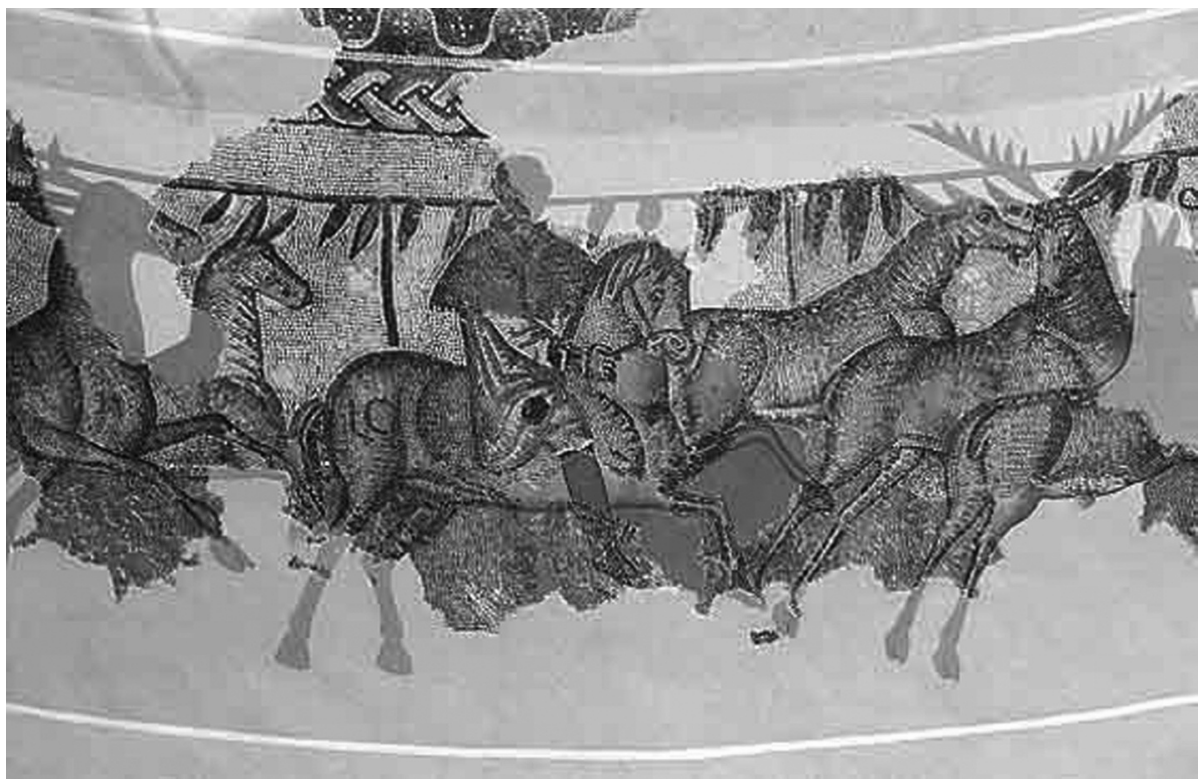

Fig. 21. Mosaico de la cúpula de Centelles. Detalle. Cacería de ciervos a caballo. Según Internet.

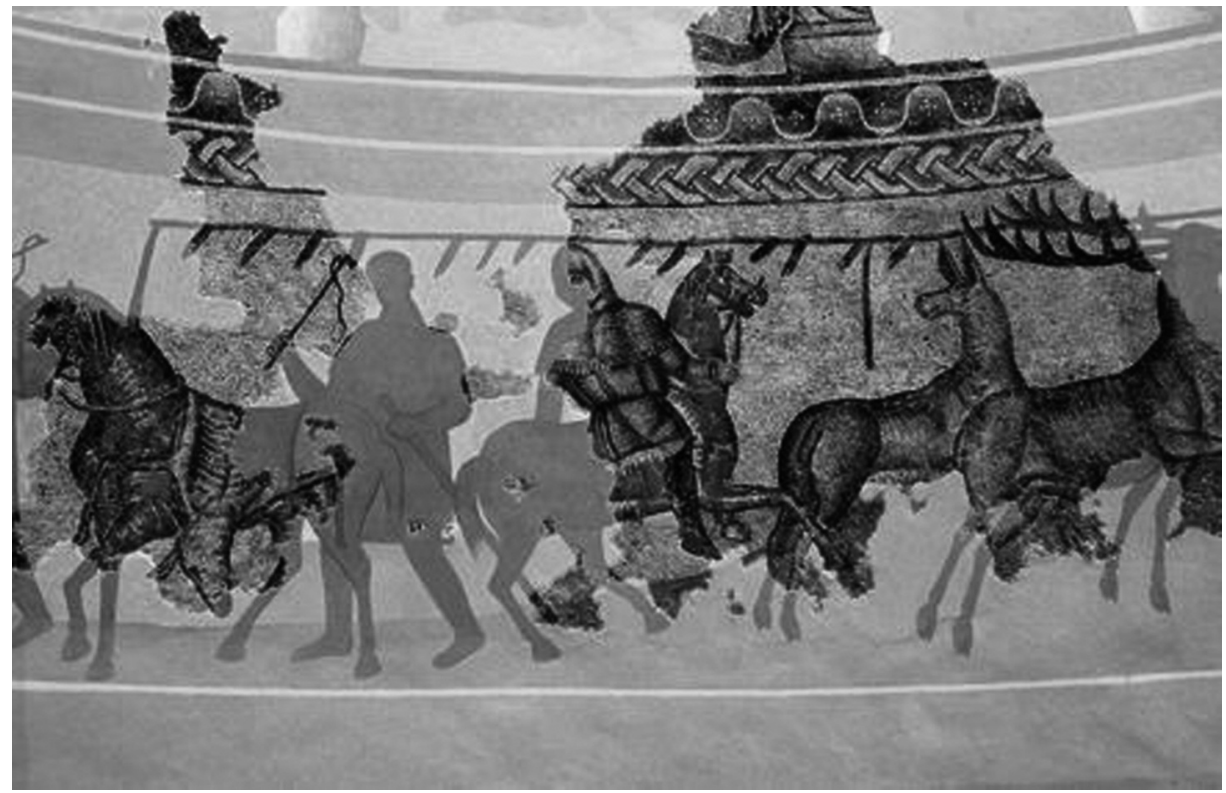

Fig. 22. Mosaico de la cúpula de Centelles. Cacería de ciervos y transporte de ciervo en caballo. Detalle. Centelles. Según Internet. 


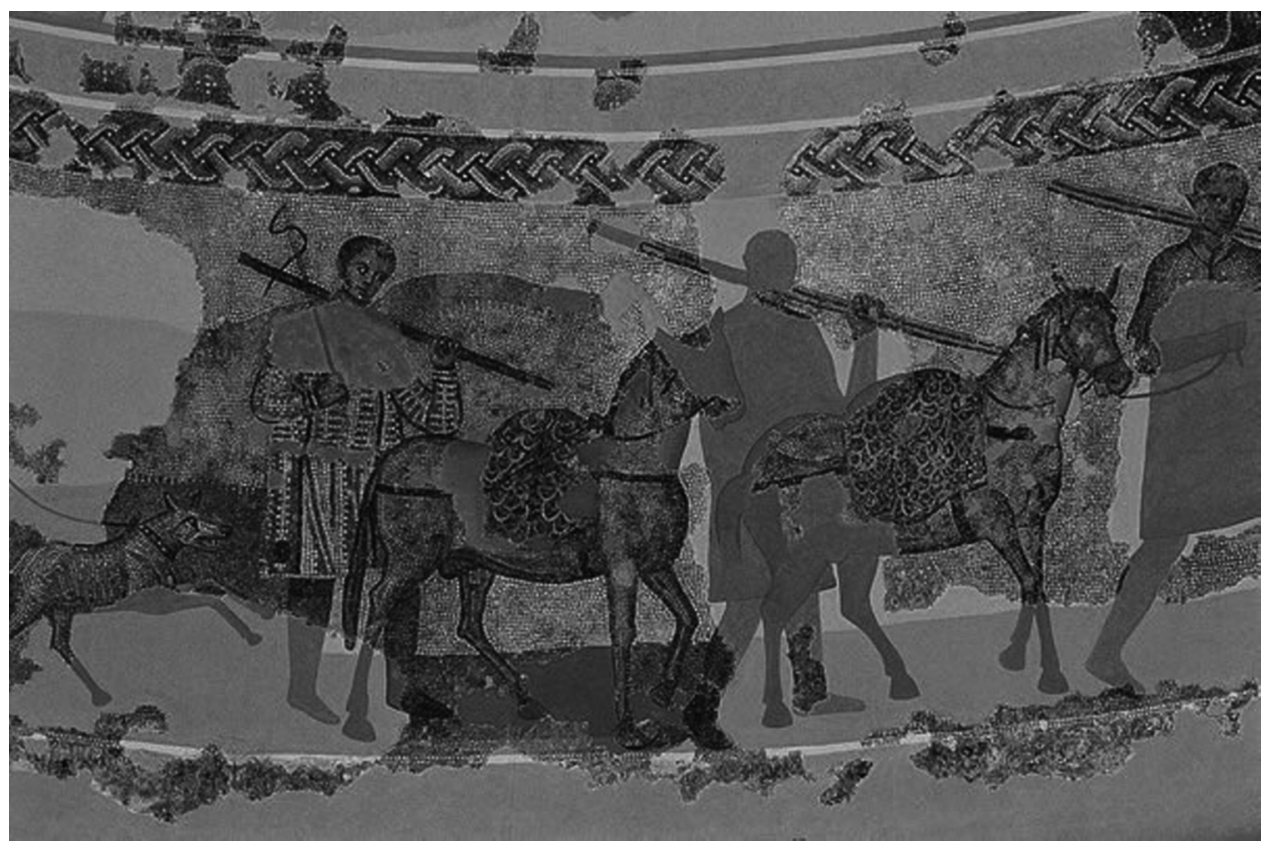

Fig. 23. Mosaico de la cúpula de Centelles. Detalle. Transporte a caballo de redes de caza. Centelles. Según Internet.

Símaco escribió pidiendo caballos a personajes que tenían yeguadas en Hispania, como puntualiza, y que varias veces con seguridad se encontraban aquí, pues les pide que ayuden a los enviados a comprar caballos. Otras veces podían ser propietarios de yeguadas en Hispania, pero no hispanos, pues los grandes capitales de la Tarda Antigüedad poseían fincas en muchas provincias, como Melania la Joven, hispana con propiedades en Hispania, Campania, Sicilia, África, Mauritania, Britannia y en otros países, según cuenta su biógrafo y acompañante, Geroncio, en la Vida de Melania (12), y Palladio (LXI). Petronio Probo ${ }^{21}$, primo de Melania, poseía fincas en casi todos los lugares del Mundo Romano, según el historiador Ammiano Marcelino (XXVII.XI.1). Había desempeñado importantes cargos administrativos, pues fue quaestor, praetor urbanus, en 364 ; praefectus praetorio Illirici, Italiae et Africae, 365-375; praefectus Galliarum, 366; cónsul en 371, y praefectus Illirici, Italiae, Africae, en 385.

Los ingresos de estos grandes capitales del Imperio eran fabulosos. Melania la Joven recibía anualmente 12.000 libras de oro y otro tanto su esposo, Piniano, cantidad que se ha interpretado como sólidos áureos.

21 JONES, A.H., MARTINDALE, J.R., MORRIS, J., Op. cit. pp. 736-740. 
En Hispania un mosaico de Mérida representa una yeguada, como el mosaico africano de la Casa de Sorothus, de Hadrumetum, datado entre los años 190-20022. En una pintura de Augusta Emérita ${ }^{23}$ (fig. 24) se representa la doma de un caballo.

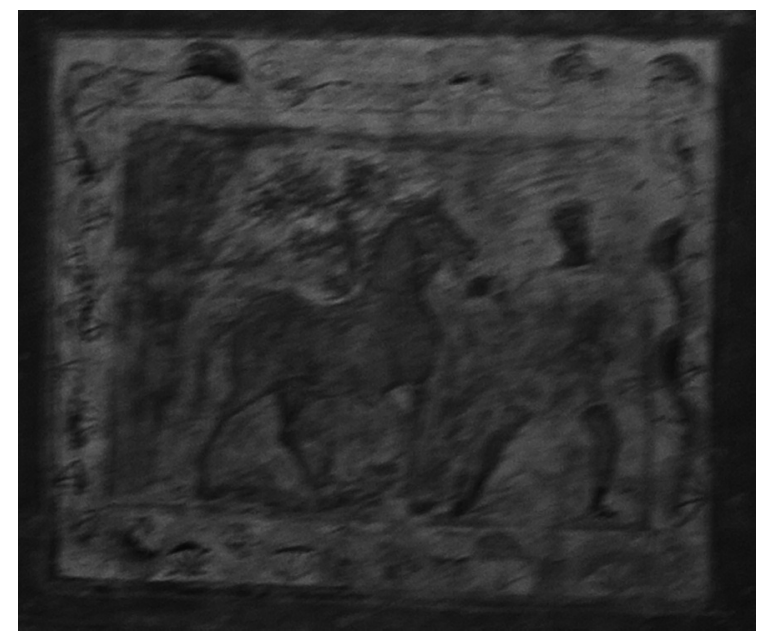

Fig. 24. Mosaico con doma de caballos. Pintura. Augusta Emérita. Según Internet.

No se dispone de una descripción de una villa hispana del Bajo Imperio como la que de su finca dejó Ausonio en la Narbonense. En cambio hay una colección numerosa de retratos de los dueños o de hijos y de hijas de los latifundistas: 18 retratos de jóvenes y de muchachas, algunos perdidos (fig. 25), decoraban el cuadro del mosaico con la leyenda de Aquiles en Skyros, de la villa de La Olmeda, Pedrosa de la Vega (Palencia) (fig. 25); las cuatro hijas, una perdida, de la villa de El Olivar del Centeno (Cáceres) (fig. 26); el devoto en el mosaico báquico de Annius Bonus, de Augusta Emérita (fig. 27); los bustos femeninos de la villa de Baños de Valdearados (Burgos); el cazador de la villa de El Ramalete (Navarra) (fig. 28); de Marianus, de Augusta Emérita; cazadores de la villa de Centelles (fig. 29); Rescia y Selenus, en la villa de Millares de la Mata, como Ménade y Sileno incorporados a la pompa triumphalis báquica; retrato de dama, de la misma villa (fig. 30 ), etc, etc ${ }^{24}$.

22 DUNBABIN, K.M.D., The Mosaics..., pp. 93-94, 113, láms. 81-82; LAPORTE, J-P., «Sousse: la domus de Sorothus et ses mosaïques», CRAl 2006, pp. 1354-1367, figs. 14, 17, 19, 21; AICHA BEN ABED KHADER, BALANDA, E., URIBE, A., Imagen de pierre. La Tunisie en mosaïque, Túnez 2007, láms. 146-148.

23 NOGALES, T., op. cit., p. 75, lám. XLII.

24 BLÁZQUEZ, J.M., El Mediterráneo y España en la Antigüedad, pp. 764-780; GARCÍA-GELABERT, M.P., «Estudio de la representación de retratos en mosaicos romanos del Norte de África y de Hispania», CMGR VIII, Túnez 1999, pp. 585-596, láms. CCXI-CCXXVIII. 


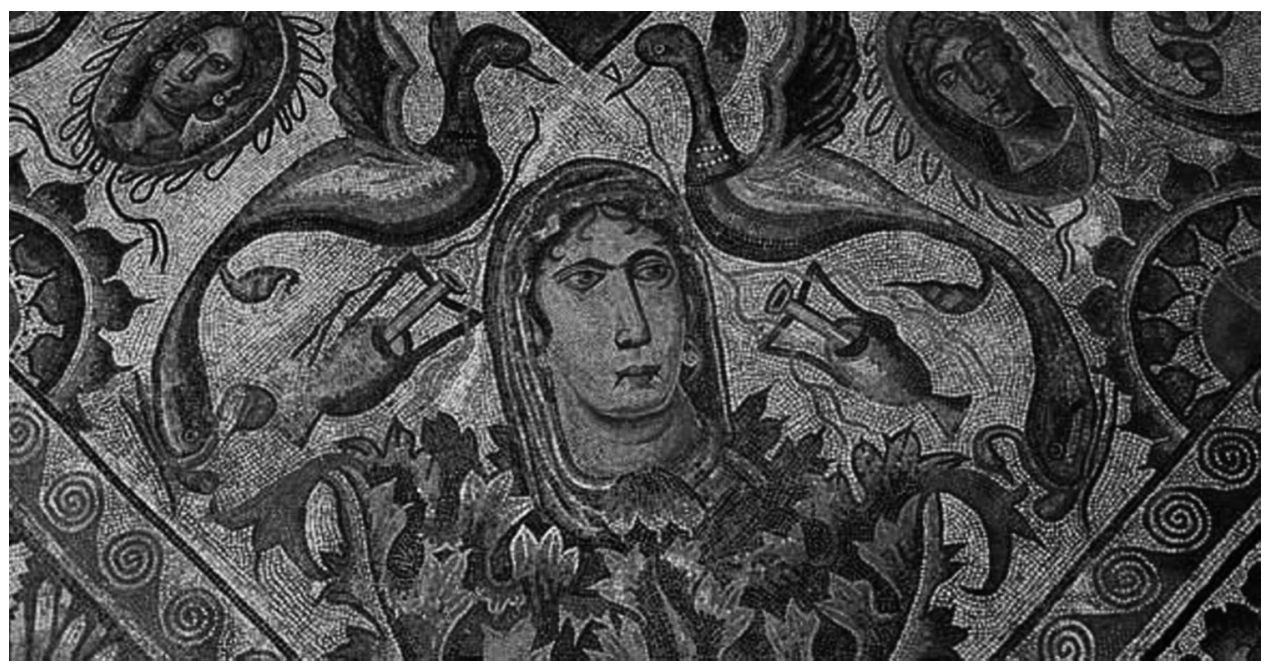

Fig. 25. Mosaico con retratos. La Olmeda. Pedrosa de la Vega. Según Internet.

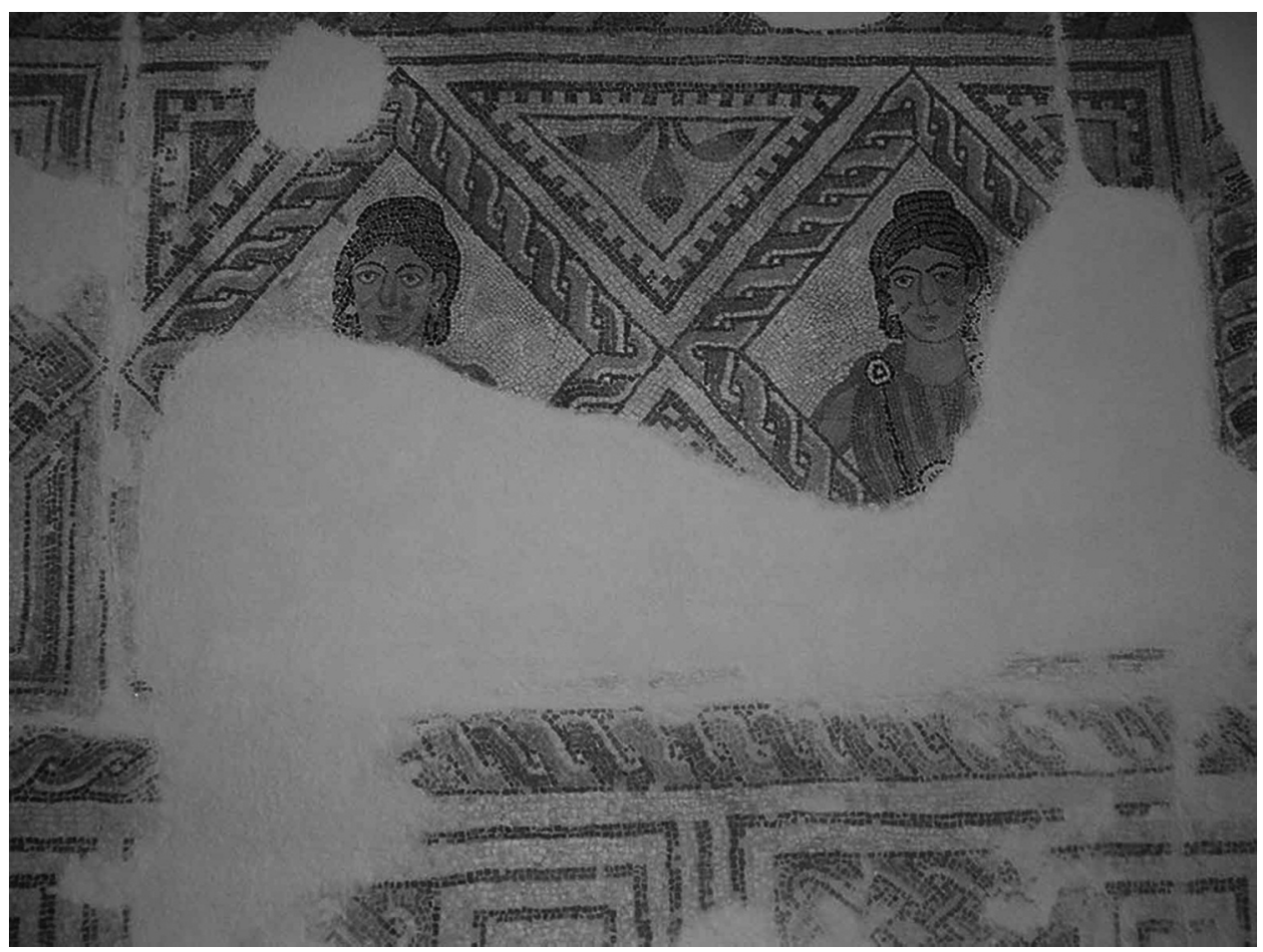

Fig. 26. Mosaico con retratos de muchachas. Villa de El Olivar del Centeno. Millares de la Mata. Según Internet. 


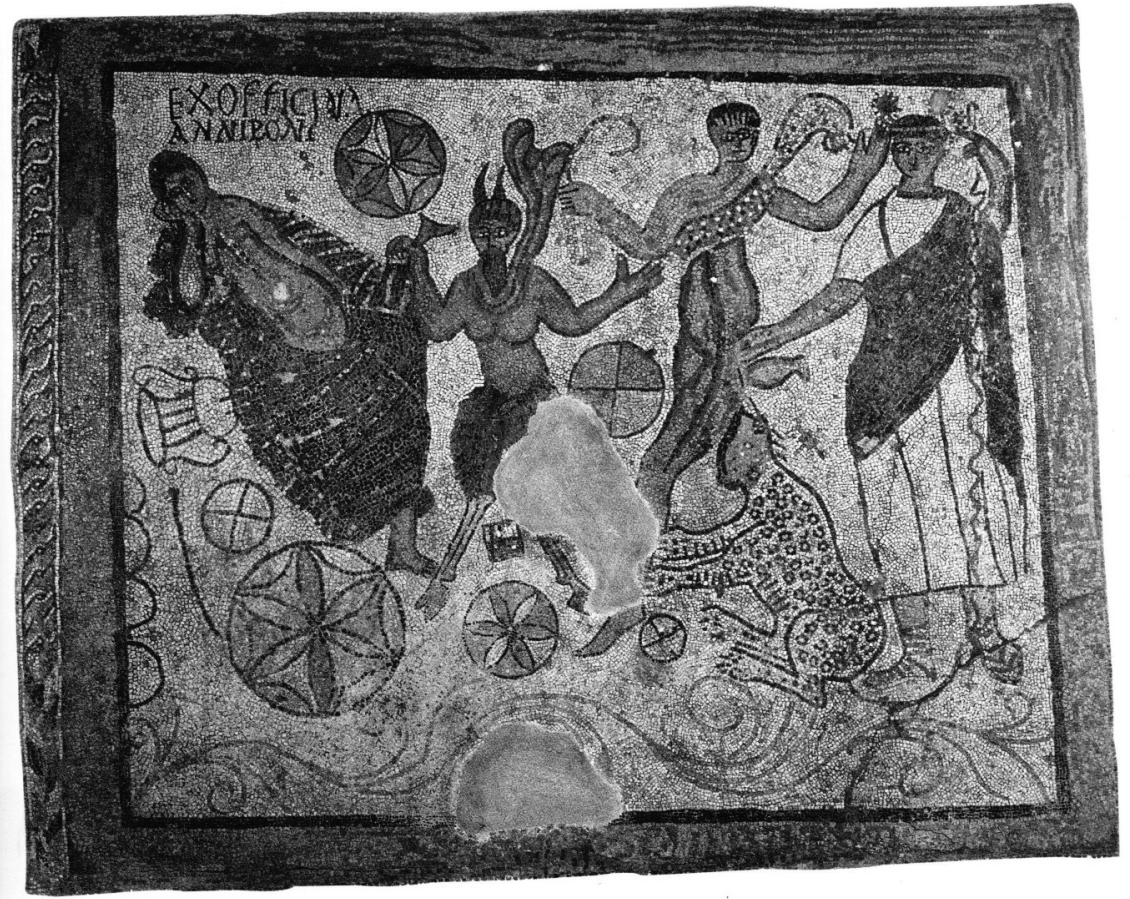

Fig. 27. Mosaico báquico con el dueño. Augusta Emérita. Según Internet.

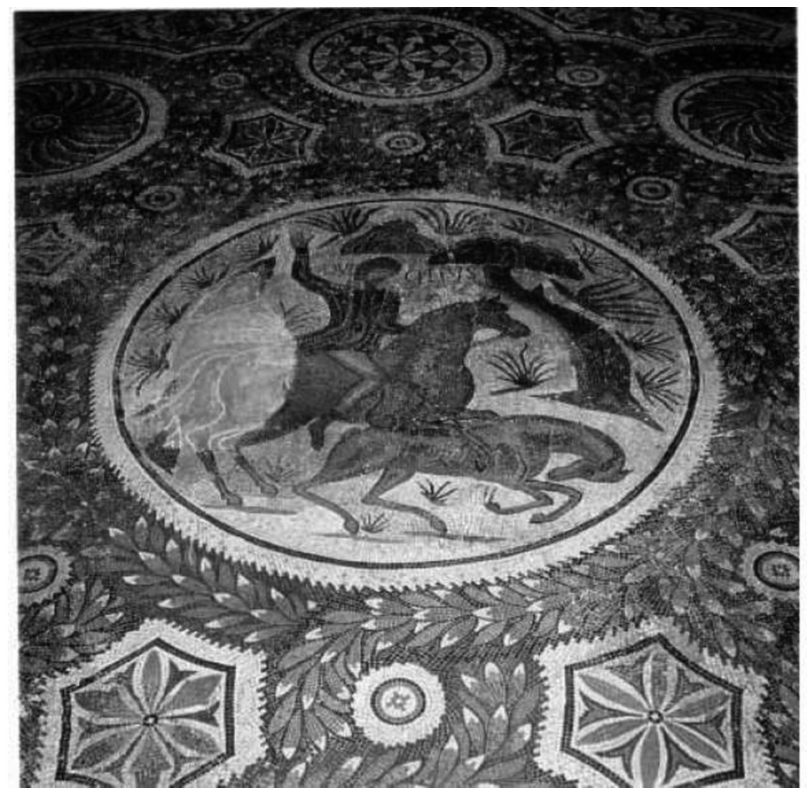

Fig. 28. Mosaico con el retrato del cazador Dulcitius. Villa de El Ramalete (Navarra). Según Internet. 


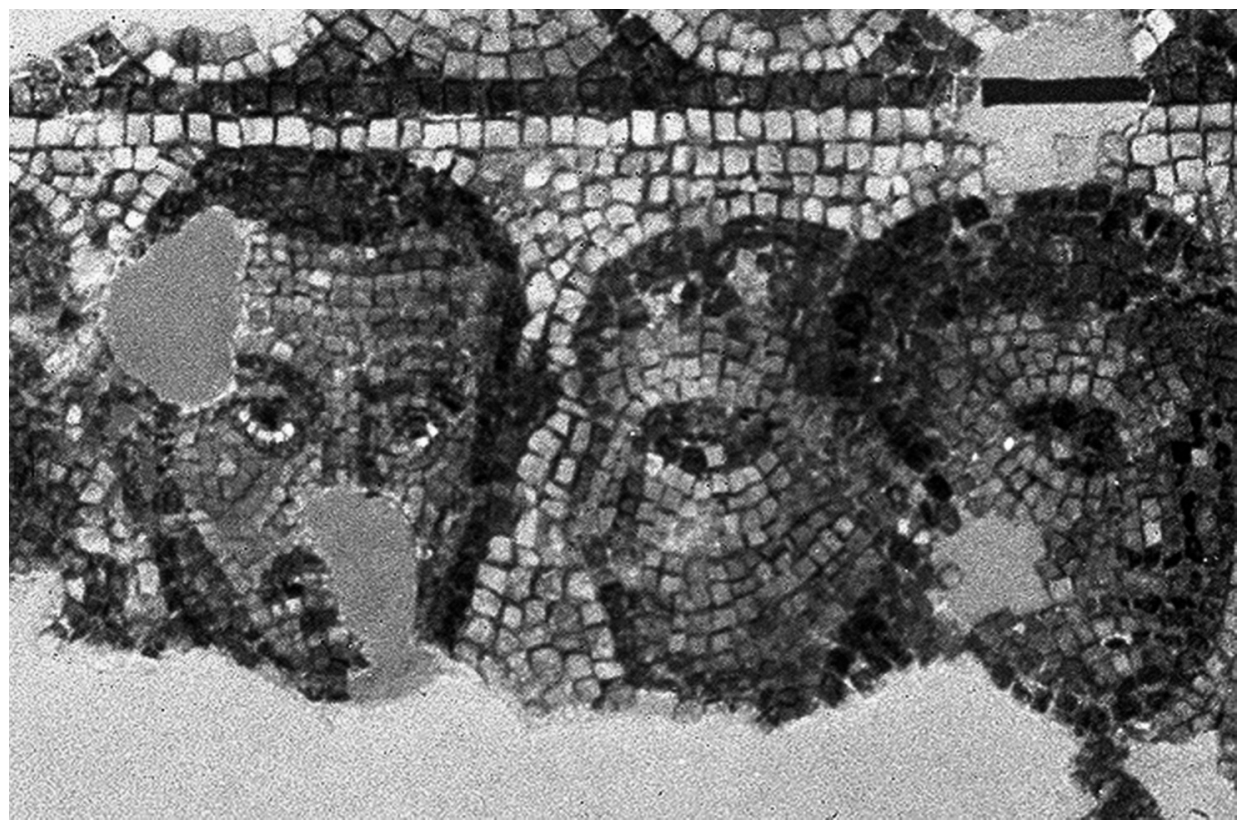

Fig. 29. Mosaicos con retratos de cazadores. Centelles (Tarragona). Según Internet.

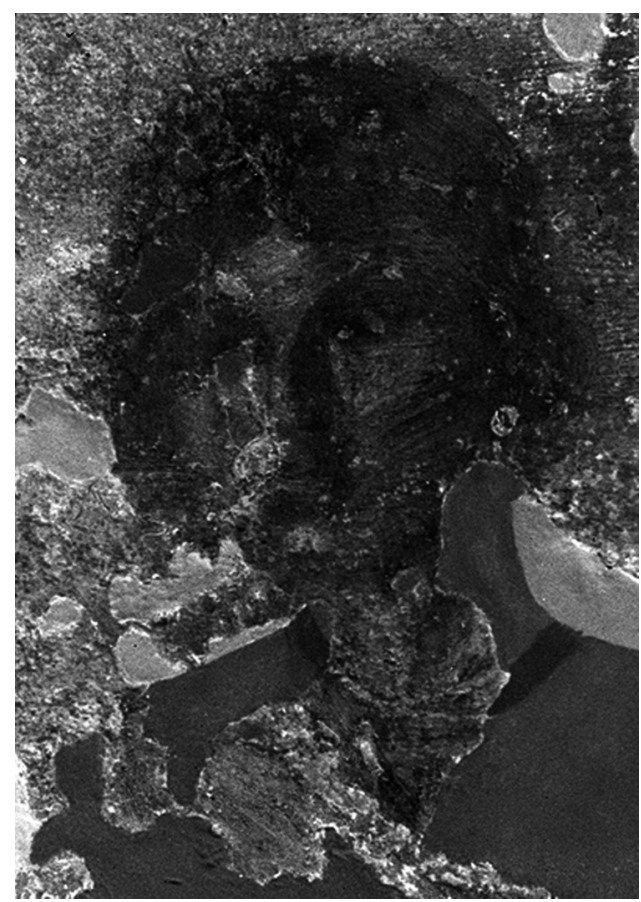

Fig. 30. Retrato de dama. Pintura. Centelles. Según Internet. 
Las villas hispanas del Bajo Imperio iban decoradas con magníficos mosaicos. El conocimiento mitológico de estos latifundistas era grande, lo que indica un alto nivel cultural ${ }^{25}$. La calidad artística de muchos mosaicos está muy generalizada. Baste recordar tan sólo tres mosaicos fuera de serie: el de Azuara (Zaragoza), con la boda de Cadmo y Harmonía (fig. 31); el de Casariche (SeviIla), con el Juicio de Paris (fig. 32), y el de Helena y Paris, de Moheda (Cuenca) (figs. 33-34).

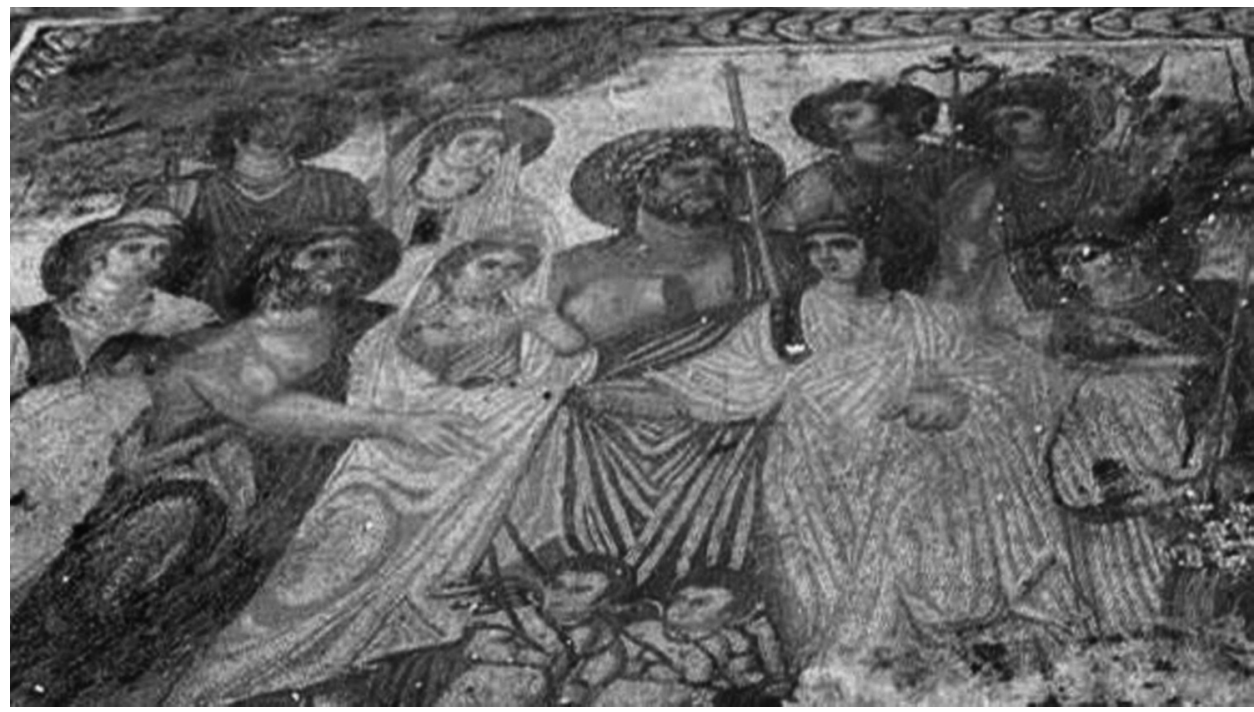

Fig. 31. Mosaico con las bodas de Cadmo y Harmonía. Azuara. Según Internet.

A. Ovadiah, uno de los mejores conocedores de mosaicos en la actualidad, me ha indicado varias veces que los mosaicos del Bajo Imperio de más calidad artística se encuentran en Hispania. Los musivarios hispanos se encontraban muy al día de las corrientes artísticas del momento, o se educaron en el África Proconsular $^{26}$ o en el Oriente ${ }^{27}$. Disponían de copy-books.

25 BLÁZQUEZ, J.M., Mosaicos romanos de España, Madrid 1993; Id., "Mosaicos romanos en Castilla-La Mancha», CARRASCO, G., La romanización en el territorio de Castilla-La Mancha, Cuenca 2008, pp. 91-125; Id., «Villas hispano-romanas del Bajo Imperio decoradas con mosaicos mitológicos», NEIRA, L. (ed.), Mitología e Historia en los mosaicos romanos, Madrid 2010, pp. 83-110; Id., «Representaciones de mujeres en los mosaicos hispano romanos», NEIRA, L. (ed.), Representaciones de mujeres y su impacto en el imaginario de esterotipos romanos, Madrid, En prensa.

26 BLÁZQUEZ, J.M., Mosaicos romanos de España, pp. 79-92; DUNBABIN, K.M.D., The Mosaics, pp. 219-222.

27 BLÁZQUEZ, J.M., «Der Einfluss der Mosaiken des vorderen Oriens auf hispanische Mosaïken an Ende der Antike», JMR 1-2, 2008, pp. 7-31. 


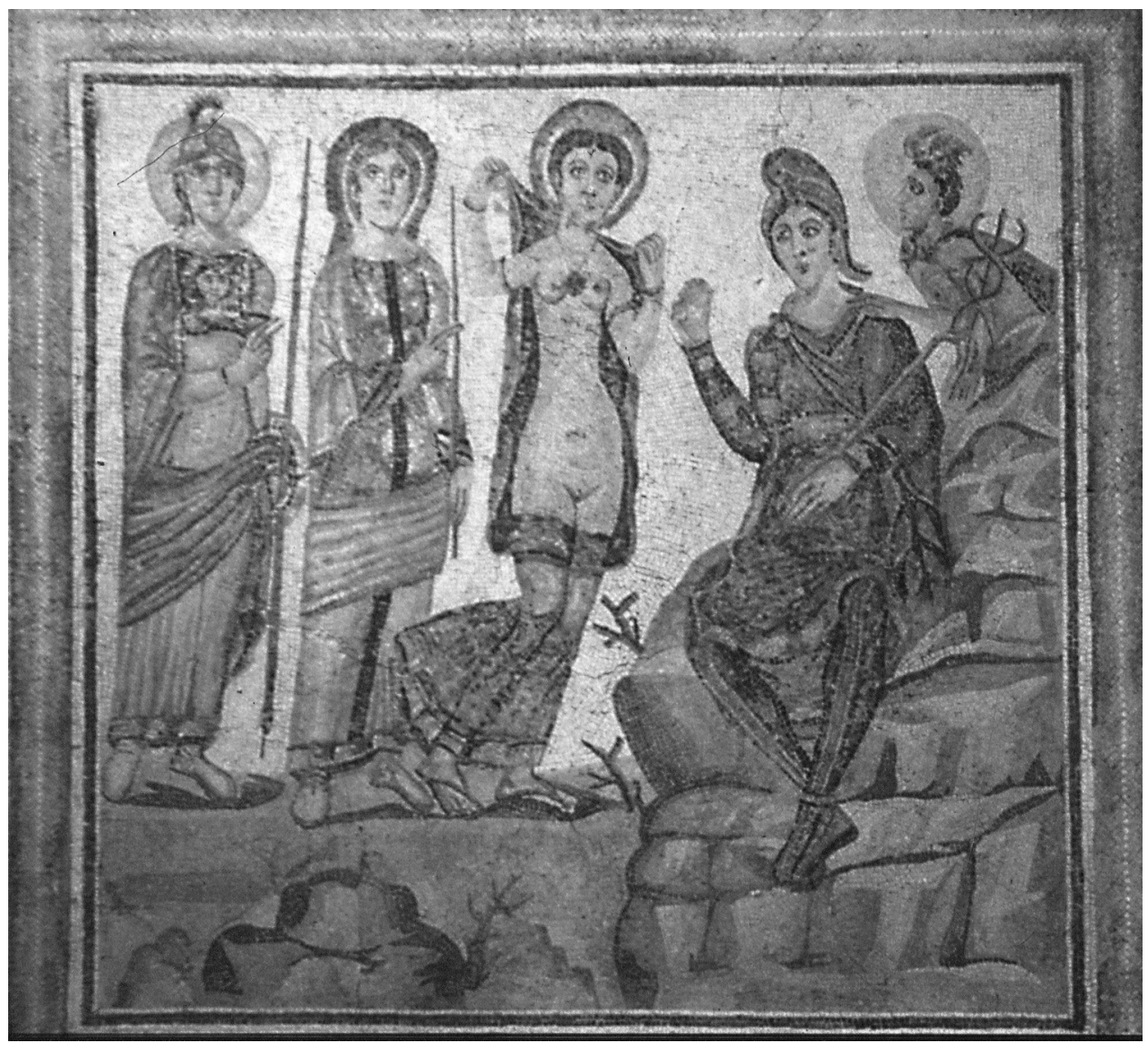

Fig. 32. Mosaico de Casariche. Juicio de Páris. Según Internet.

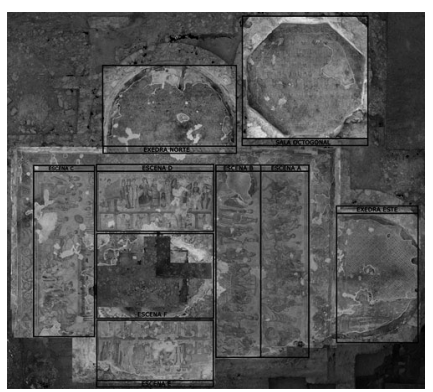

Fig. 33. Mosaico de Noheda (Cuenca). Nave. Helena y Páris. Foto J. y M. Latova. 


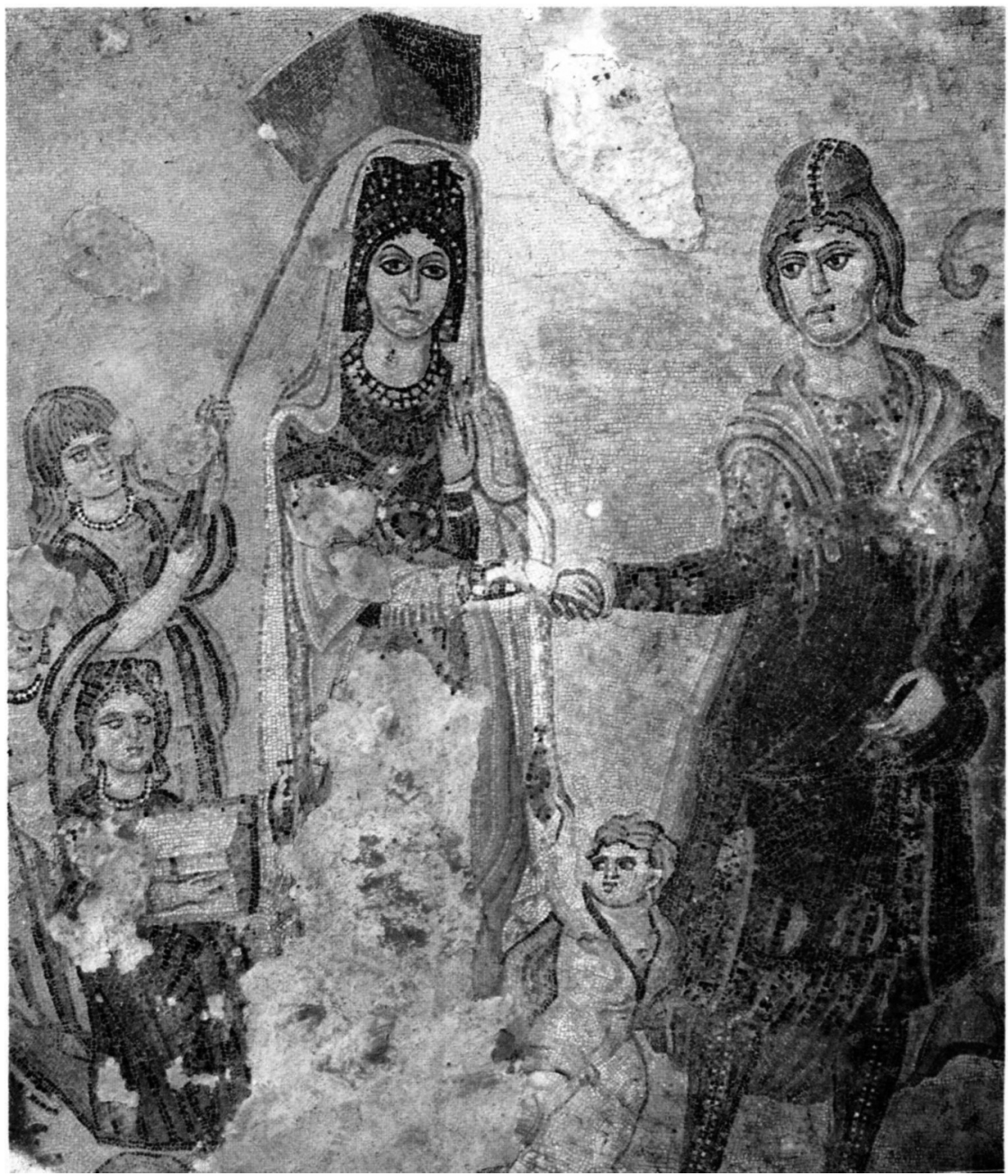

Fig. 34. Mosaico de Noheda. Helena y Páris. Foto J. y M. Latova.

Se han hecho buenas reconstrucciones de villas hispanas de la Tarda Antigüedad, como de las villas de Almenara de Adaja (Valladolid) ${ }^{28}$; de Aguilafuente $(\text { Segovia })^{29}$, y de Rielves (Toledo) ${ }^{30}$. Todas se encuentran en el centro de Hispania, y de la Villa Fortunatus (Fraga, Huesca), en los Pirineos.

28 FERNÁNDEZ CASTRO, M.C., Villas romanas de España, Coslada 1982, p. 107.

29 FERNÁNDEZ CASTRO, M.C., op. cit., p. 109.

30 FERNÁNDEZ CASTRO, M.C., op. cit., p. 111. Sobre las villas hispano romanas, además de este libro: FERNÁNDEZ OCHOA, C. et Alii, Las villae tardorromanas en el Occidente del Imperio. Arquitectura y función. IV Coloquio Internacional de Arqueología en Gijón, Gijón 2008; GORGES, J-G., Les villes 
La simple planta de la villa indica la magnificencia del edificio, como en las villas de Carranque (Toledo); de Cuevas de Soria (Soria); de Santervás del Burgo (Soria) (fig. 41), y de Bruñel.

La mayoría de los latifundistas eran paganos. La Pasión, del s. V., de San Saturnino, primero obispo de Tolosa, mártir de la persecución de Decio, año 250, describe a Hispania como fundamentalmente pagana. Las Actas del Sínodo de Elvira (Granada), de comienzos del s. IV, señalan la concentración del cristianismo en el sur. Amplias zonas no tienen representantes de comunidades cristianas, y los mártires de la persecución de Diocleciano, años 303-311, fueron pocos ${ }^{31}$.

hispano-romaines. Inventaire et problematique arquologiques, París 1979; MEZQUIRIZ, M.A., «Las villae tardorromanas del Valle del Ebro", Trabajos de Arqueología, Navarra 21, 2009, pp. 199-272.

31 BLÁZQUEZ, J.M., «La Iglesia hispana. Orígenes en Lusitania», GONZÁLEZ BLANCO, A., VELÁZQUEZ, A. (eds.), Los orígenes del cristianismo en Lusitania. CEP 34, pp. 61-100. 
